S F

259

.87

singy 


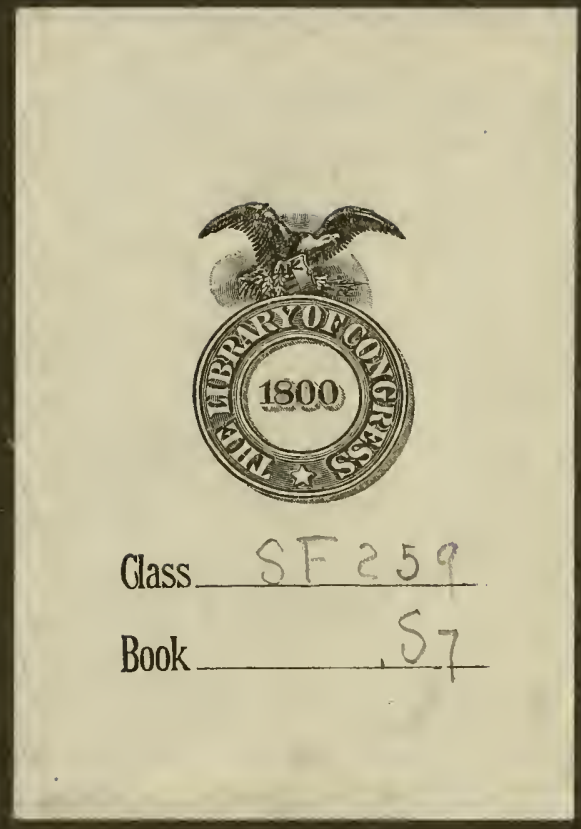


TREASURY DEPARTMENT

\title{
UNITED STATES PUBLIC HEALTH SERVICE
}

HUGH S. CUMming, Surgeon General

\section{STUDIES OF RECONSTRUCTED MILK}

\author{
BY \\ ALBERT F. STEVENSON \\ Sanitary Engineer \\ GEORGE C. PECK \\ Scientific Assistant \\ AND \\ C. P. RHYNUS \\ Assistant Sanitary Engineer \\ United States Public Health Service
}

REPRINT No. 608

FROM THE

PUBLIC HEALTH REPORTS

AUgust 27, 1920

(Pages 2011-2045)

$20-21519$

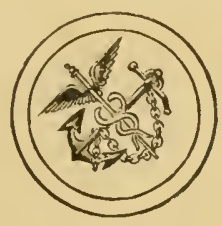

WASHINGTON

GOVERNMENT PRINTING OFFICE 
ADDITIONAL COPIES

OF THIS PUBLICATION MAY BE PROCURED FROM THE SUPERINTENDENT OF DOCUMENTS GOVERNMENT PRINTING OFFICE WASHINGTON, D. C.

AT

5 CENTS PER COPY

$\nabla$

A. 2. D.

DEC $\quad 11$ (920)

.$\vdots \vdots$ 


\section{STUDIES OF RECONSTRUCTED MILK. ${ }^{1}$}

By Albert F. Stevenson, Sanitary Engineer; George C. Peck, Scientific Assistant; and C. P. RHYNUS, Assistant Sanitary Engineer, United States Public Health Service.

\section{FOREWORD.}

By Earle B. Phelps, Consultant, United States Public Health Service.

Pure milk contains a variety of substances, which, for convenience in analysis and reference, are conventionally divided into three groups: Fats, solids not fat, and water. The proportions of these three groups in the mixture vary with the breed of cattle, the feed, the season, and other variable conditions, but it will be sufficiently accurate for the present purposes and for illustration to say that normal milk contains $3 \frac{1}{2}$ per cent fats, 9 per cent solids not fat, and $87 \frac{1}{2}$ per cent water.

At a time when, in the interests of food conservation, the possibilities of desiccated foodstuffs are being developed and their economic advantages exploited, it is unnecessary to dwell at length upon the purely economic benefits which would accrue were it possible to deal with the milk supply of the country and, especially, with its problems of storage and transportation, upon a water-free basis.

Desiccation in general has two principal advantages: It reduces the weight of the commodity, thereby simplifying the problem of distribution; and it improves the handling and keeping qualities of perishable foods by doing away with the watery environment necessary for microbial activity. These advantages make it possible to distribute foodstuffs over wide geographical areas and thus to provide markets for those regions in which production is deficient or lacking. They also make possible a seasonal distribution or leveling, whereby the commodity may be carried over from a season of excessive production into a season of nonproduction.

To these manifest advantages, which are common in the entire field of desiccated food, there is added, in the case of milk supplies, a third of equal if not greater importance. This has reference to the sanitary aspects of the milk problem, which have so occupied the attention of public-health workers in recent years. Milk provides so favorable a medium for the growth and multiplication not only of normal and relatively harmless bacteria but also of the specific organisms of disease that the entire development of this important food supply,

! Made under the supervision of Earle B. Phelps, Consultant, United States Public Health Service. Reprint from the Public Health Reports, vol. 35, No. 35, Aug. 27, 1920, pp. 2011-2045. 
especially as it relates to large cities, has been impeded and very seriously complicated by the necessary public-health restrictions. The storage and shipping of milk must be done at low temperature and can not extend beyond a few days at most, and pasteurization has come to be a recognized essential feature in the handling of a city milk supply.

If, now, it were possible to desiccate the product in its fresh condition by a process which would greatly reduce the existing bacterial life and prevent the further multiplication of the surviving organisms, the limitations referred to would in large measure disappear.

The actual realization of these conditions and the possibility of supplying to a community a milk reconstructed from its previously desiccated components and water, have been made possible by a series of steps, the commercial development of which has been taking place for many years. These are the mechanical separation of the fats in the form of cream from the skimmed milk, and modern processes of butter making; the development of processes, first, of skimmed milk evaporation, and, finally, of complete desiccation to a powder containing, in readily soluble form, all the milk solids except the fats; the development of mechanical means of emulsifying butter fat in water or skimmed milk solution, thus reconstructing the cream; and, finally, the conception of reconstructing a whole milk, by emulsifying butter fat into a solution of milk solids of proper strength.

This paper is a report of what is believed to be the first experiment upon a commercial scale with reconstructed milk. While the advantages of the plan, under many conditions, are so obvious that the idea had frequently been discussed, there were at the outset of this investigation certain difficulties to be overcome. In order to prevent fraud and protect health, it has been necessary for the States and the Federal Government to enact food laws which prohibit, in large measure, modification of natural food products. This raised the question of the propriety of the proposed procedure, which admittedly makes fraud, in the terms of the pure food law, easy and its detection difficult.

The particular situation which has been created by the possibilities of reconstructed milk is without precedent, and, as it deals with one of the most fundamental of the human foods, a most conservative attitude upon the part of the officials charged with the enforcement of the pure food laws has very properly been maintained. In view, however, of the tremendous advantages which are foreseen in the development of this field, it is believed that the problem must be handled entirely upon its own merits, and with the utmost frankness. There cau be no question of the impropriety of handling reconstructed 
milk, except under its own label and with complete information as to its source and method of preparation. If it can be shown, however, that reconstructed milk can be marketed in a community uncier cleaner and safer conditions and at less cost than can ordinary milk, the consumer is entitled to these advantages just as he is also entitled to know exactly what he is purchasing, and, if he prefers to use fresh cows' milk, to be assured that he receives that for which he asks and pays.

A second possibility which has prevented more active development of reconstructed milk has been the fear that the public might be slow to appreciate its advantages and reluetant to give up a part of the dietary so well established as milk in favor of what must appear to be a sort of manufactured product. While this argument will carry no weight whatever among physicians, dietitians, and others competent to look into the subject with sufficient thoroughness, it is a matter to be reckoned with most thoughtfully by one who would undertake the commercial development of a market for reconstructed milk.

In the situation which arose at the new Government city of Nitro, W. Va., both of these objections lost most of their forec. A city to house some 25,000 people was being built overnight, and was without any visible milk supply, nor did it seem probable that a sufficient supply of safe milk could be obtained. The health administration of this city was to be in charge of the United States Public Health Service, so that there could be no question of conflict with traditional health regulations. The conditions made it unnecessary to fear competition with normal milk, so that it was practically assured in the beginning that, if the milk was satisfactory, a market would be secured. Under these favorable conditions a plan which had been gradually maturing was put into effect, and the present paper is a report of the results obtained. Unfortunately for this particular purpose, the experiment had to be discontinued before the complete data that were hoped for had been gathered. It is believed, however, that the results obtained are of so great importance that the outcome of this first commercial demonstration of the possibilities of reconstructed milk should be recorded.

Mr. Stevenson designed the plant and prepared the specifications for the mechanical equipment and has been wholly responsible for the planning and execution of the experimental work. He has been ably assisted throughout by Mr. Peck who was in resident charge during the construction period, and who, in the capacity of superintendent, was directly responsible for the operation of the station.

Mr. C. P. Rhynus made the bacteriological studies, and Mr. Leslic Z. Peck served as assistant superintendent. 


\section{THE MANUFACTURE AND HANDLING OF RECONSTRUCTED MILK AT NITRO, W. VA.}

By Albert F. Stevenson, Sanitary Engineer, and George C. Peck, Scientific Assistant, United States Public Health Service.

\section{Introduction.}

Nitro, W. Va., is located on the Kanawha River, about 13 miles from Charleston. It. was built by the United States Government to house the laborers and mechanics employed in building the United States Explosives Plant C and later to house persons permanently employed in the smokeless-powder plant. Accommodations were made for about 25,000 inhabitants. The several institutions and industries necessary to form a well-organized community, such as schools, churches, hospitals, department stores, restaurants, water supply, sewerage, abundant food supply, etc., were provided. In short, a modern city was constructed on the land surrounding the explosives plant.

The construction of this city and the organization of the various necessary secondary industries was accompanied by many difficulties which were increased by war-time conditions. The gathering together of sufficient food of satisfactory quality proved to be one of the serious difficulties, and radical departures from current practice were made in order to overcome them. One of the most interesting and instructive divergencies was made in securing a sufficient quantity of fluid milk to satisfy the demand. The present article deals with this part of the work.

\section{Available Normal Source of Milk.}

Very little milk is produced in West Virginia in the vicinity of Nitro. The region is mountainous and little if any natural pasturage is available. In fact, previous to the building of the various Government industries located in this section, hardly enough local milk was available to supply the normal Charleston market. Up to the time Nitro was conceived, little attempt was made to increase the supply. Some milk was shipped in from the dairy section of Ohio, but with the advent of war, the scarcity of milk and the congestion of railroad traffic made this source undependable. The United States Public Health Service was called on to suggest some method of procuring a milk supply for Nitro.

\section{Reconstructed Milk Products.}

For some time it has been known that a liquid closely resembling milk and cream could be made by emulsifying butter fat obtained from unsalted butter in a solution of skimmed milk powder or diluted evaporated skimmed milk. This procedure has been very widely 
used by the ice-cream industry and has been sanctioned for this purpose by the pure-food officials. This liquid has also been made in small quantities at some Army field hospitals, and on several of the battleships to furnish a supply to the officers' mess. It has been made at various dairy and milk shows as a means of advertising milk powders.

The manufacture of reconstructed products on à small scale led to the assumption that a fairly large-sćale plant could be successfully operated and the milk supply of a city the size of Nitro manufactured. After conferring with officials of the department of health and sanitation and the commissary department at Nitro, it was decided to recommend the building and equipping of a plant of sufficient capacity to supply the entire city with reconstructed milk and cream. It was certain that milk could be made which wotld be satisfactory if consumed within a few hours of the time of manufacture; but little, if anything, was known about the cost of manufacture, the method of handling, and the keeping qualities of the products.

In order to make a thorough investigation of the subject and at the same time supply Nitro with milk, the Public Health Service undertook to design the plant and superintend its operation as long as the process was in the experimental stage. An equipment was designed which, it was estimated, would handle 2,000 gallons of bottled milk in an eight-hour day, and which capacity could be increased to 3,000 gallons per day by the addition of another pasteurizing and emulsifying unit. Milk and cream could be handled in either bulk or bottled form, although equipment of sufficient size to bottle all the output was provided. It was expected that all milk sold, except that used for cooking, would be served in bottles.

\section{Description of Building.}

The "milk plant" was located in the south end of the reservation in a one-story frame building 150 feet long and 51 feet wide. This same building also housed a small cold-storage warehouse used by the commissary department for the storage of perishable foods. The space allotted to the manufacture of reconstructed milk was 123 feet long and 51 feet wide. This space was somewhat excessive, but on account of the experimental character of the work, extra room was provided. The geineral plan of the building is shown in Figures 1 and 2 , and a sectional elevation in Figure 3 . The building was divided into eight rooms: A milk manufacturing room; a room for the washing of containers; cold-storage space for milk and butter; a dressing room; a storage room for milk powder; an office; and a room for the refrigerating machinery. 


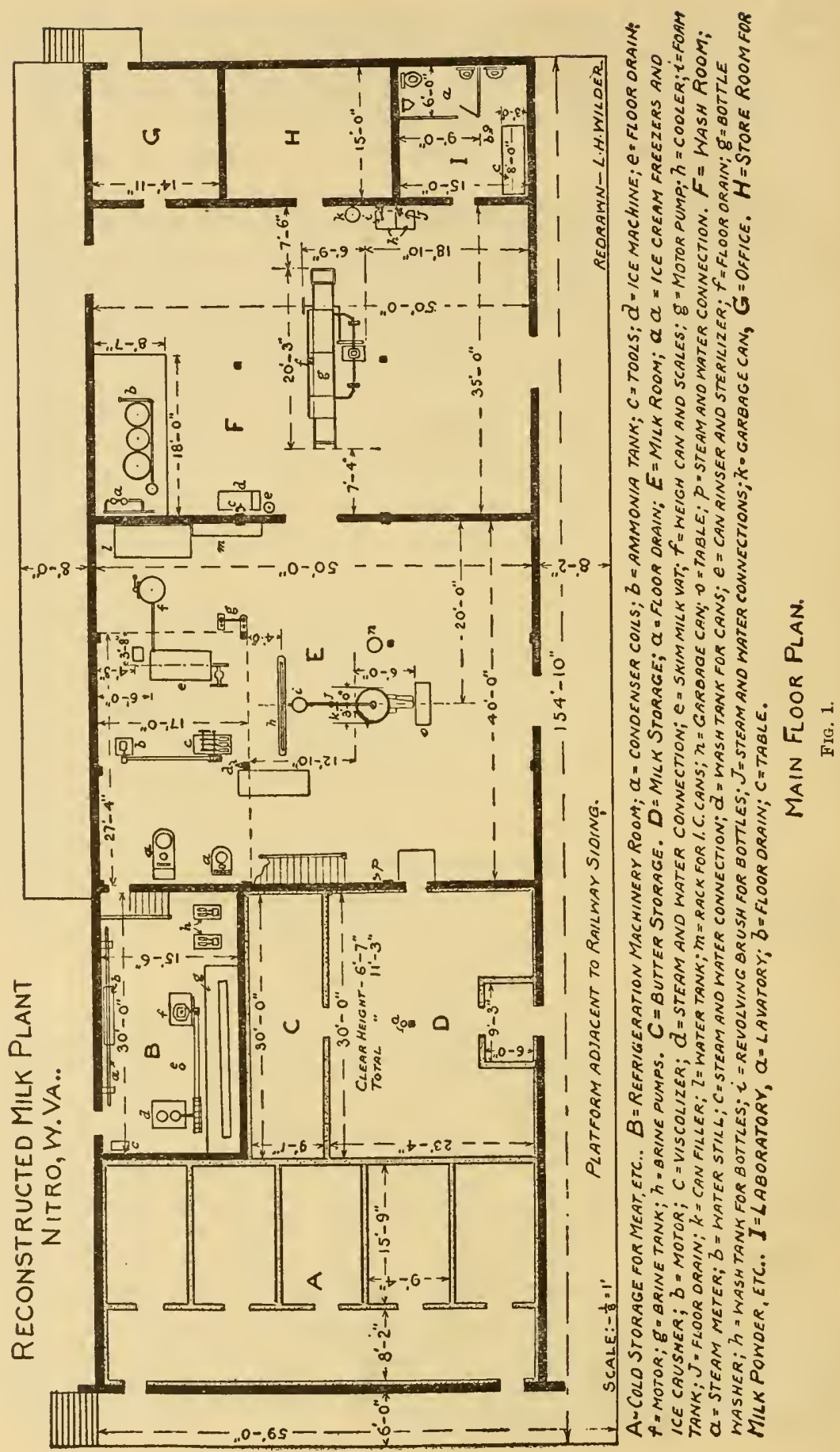


The milk room was 40 feet long and 50 feet wide. In the southwest corner was located a balcony, elevated $8 \frac{1}{2}$ foet from the main floor. This balcony was 27 feet long and 17 feet wide. An emergency exit from this room to the west platform was provided, but it was kept locked while the plant was in operation.

The washing room was 35 feet long and 50 feet wide. In the southwest corner of this room was located a platform 8 by 18 feet, raised about 6 inches from the main floor. It could be entered from both outside platforms.

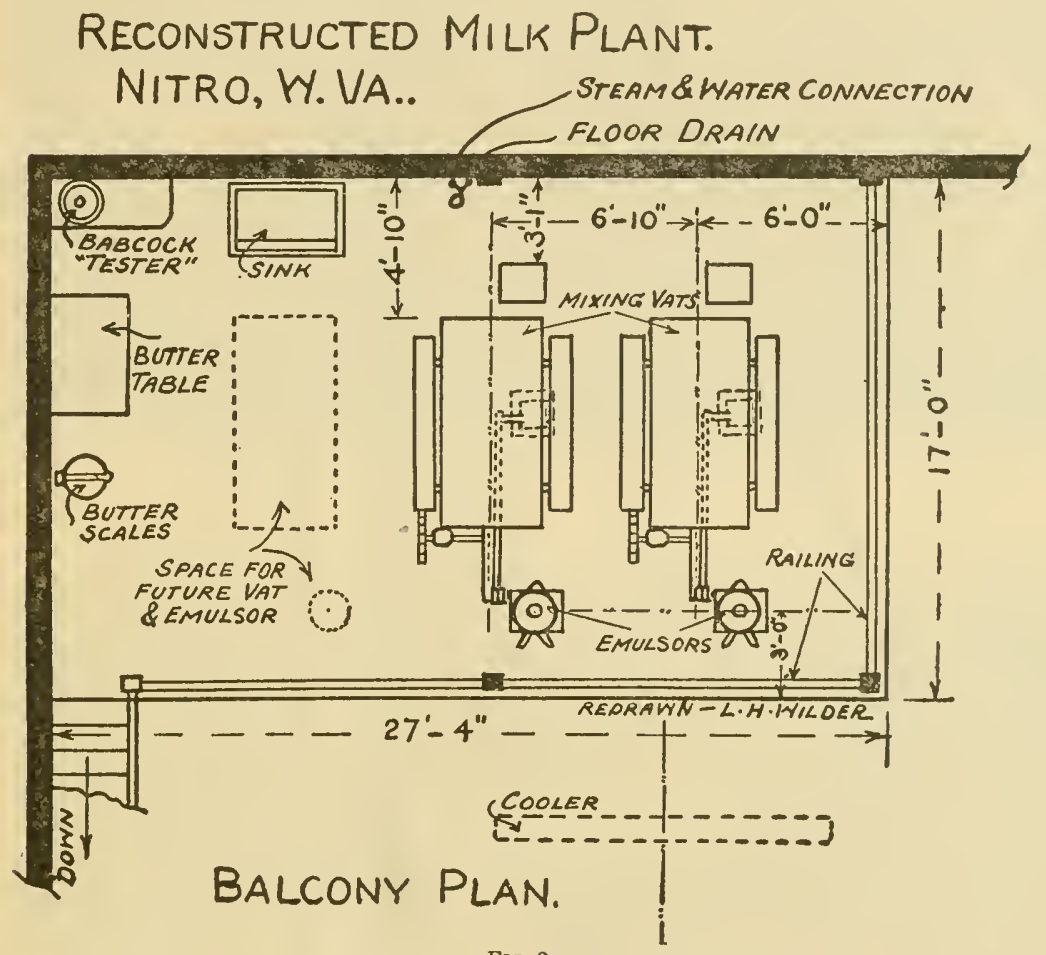

Fig. 2.

The refrigerator was 30 feet long by 23 feet wide. It could be entered from the milk-manufacturing room through a single refrigerator door, or from the east platform through two doors and a vestibule. The room was large enough to store one day's output of the plant, together with a carload of ice.

The butter-storage room was 30 feet long by 9 feet wide. It could be entered only from the milk-storage room. This room was large enough to store two carloads of butter. Both of the cold-storage rooms were insulated with rock cork and were plastered inside with cement plaster. 'They had an available head room of 6 feet 7 inches. 
STUDIES OF RECONSTRUCTED MILK.

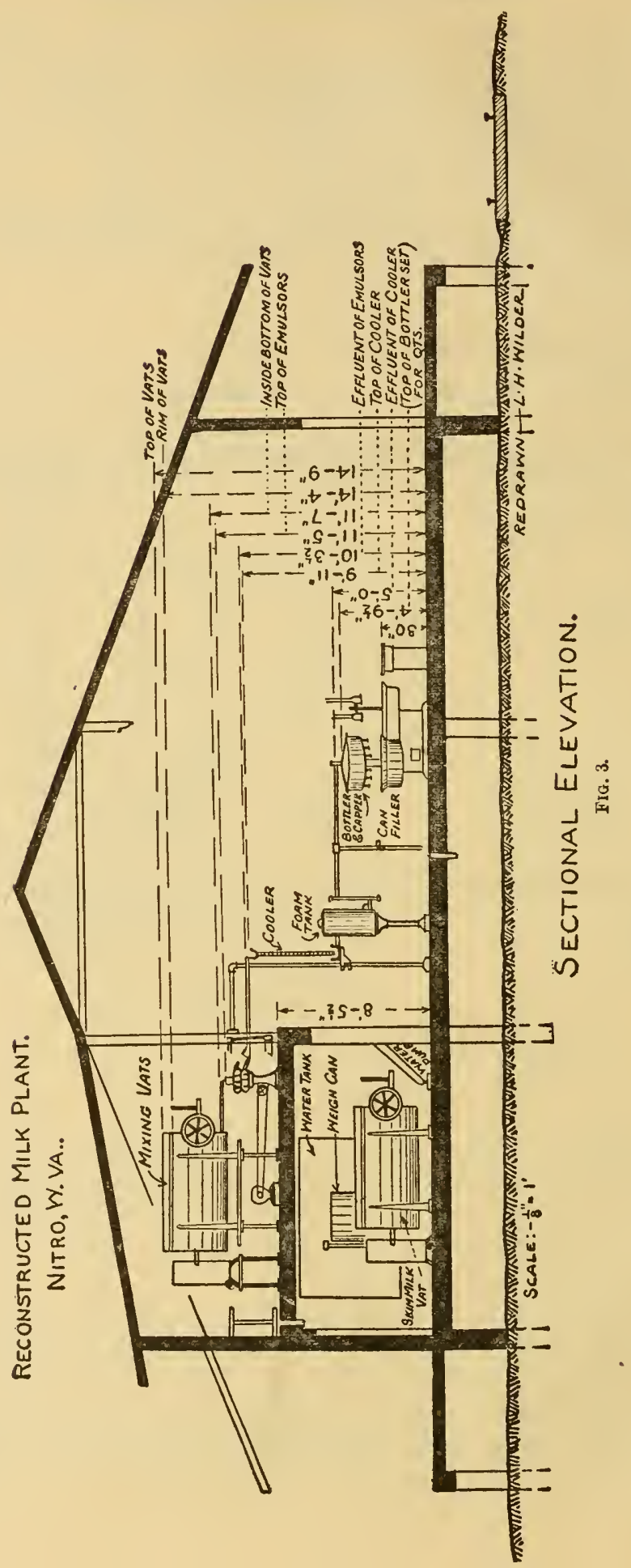




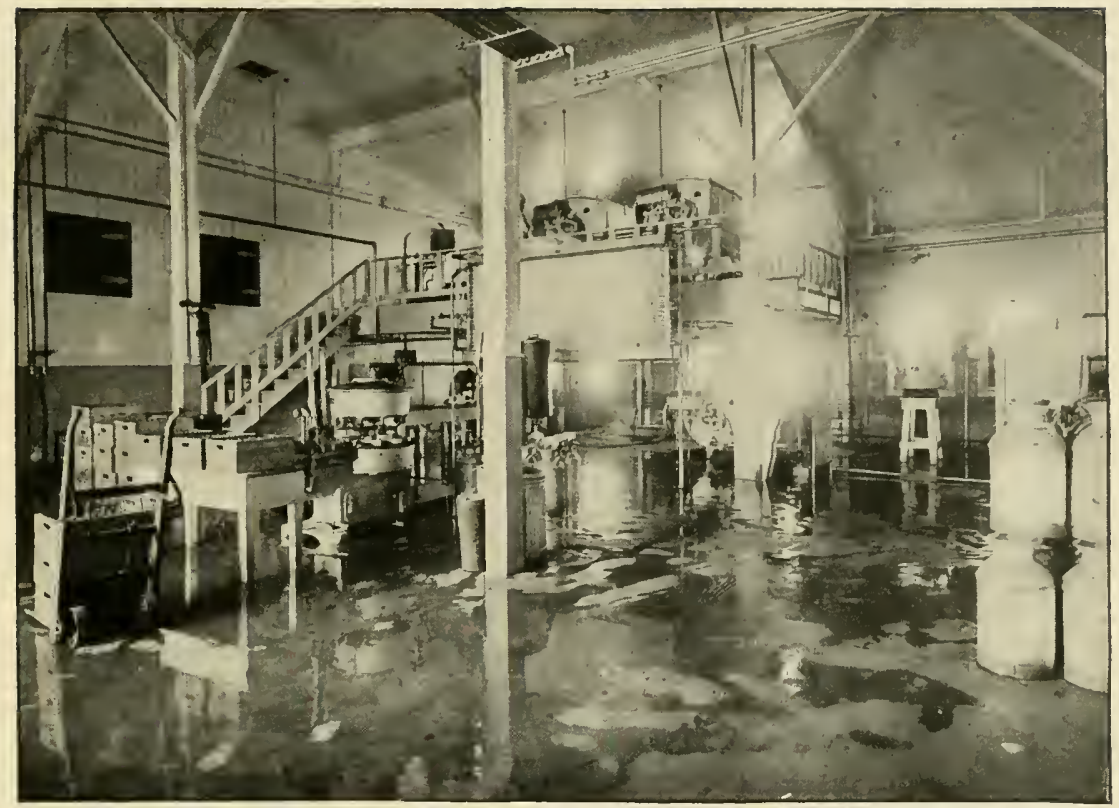

Fig. 4.- Manufacturing and bottling room, Reconstructed Milk Plant, Nitro, W. Va.

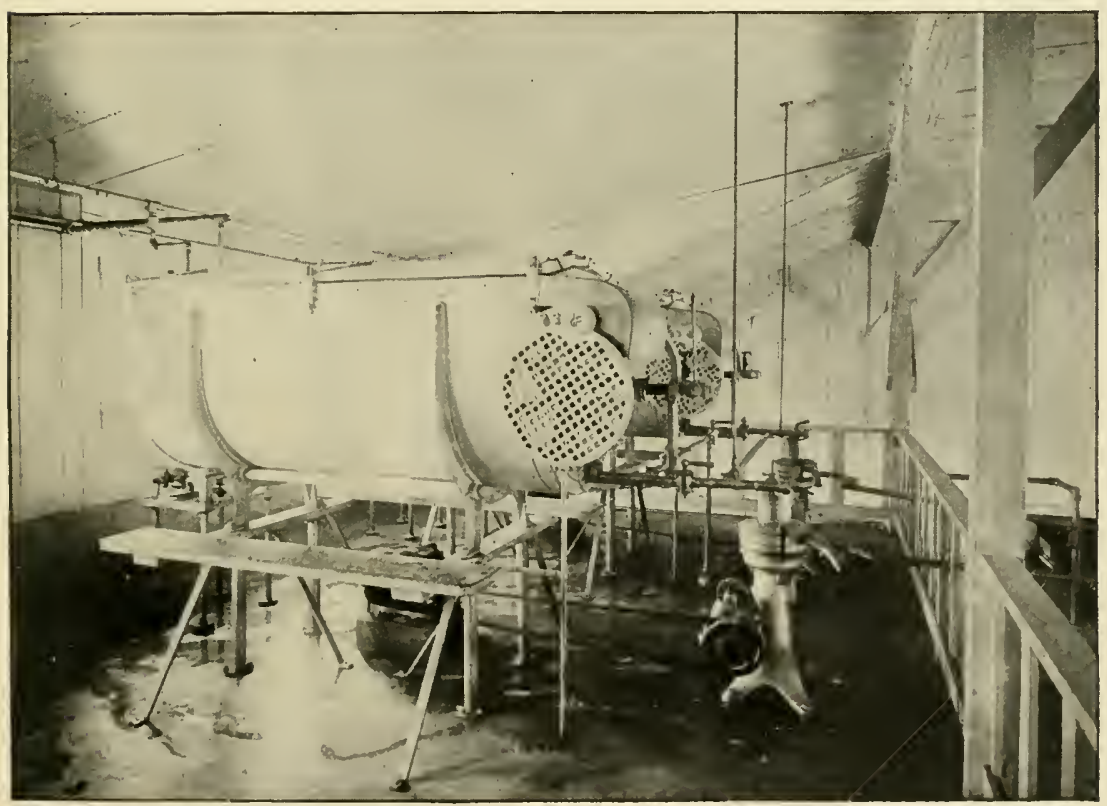

Fig. 5.-Mixing vats and emulsors, Reconstructed Milk Plant, Nitro, W. Va. 
The dressing room was approximately 15 feet square, and could beentered from the wash room. It contained hand bowls and toilets and lockers for clothing.

The room for the storage of milk powder, which was 20 feet by 16 feet, was of sufficient size to store 100 barrels.

The office was 16 feet square and contained a desk, chairs, a table, and a telephone. The office could be entered from the outside and also from the washing room. This outside entrance was the only entrance used by those not employed at the plant.

The room containing the refrigerating machinery was 30 feet long by $15 \frac{1}{2}$ feet wide. The floor of this room was at the ground elevation and could be reached by a short stairway leading from the milk room.

The main floor of the building was made of heavily reinforced concrete, and was elevated about 5 feet above the ground level. It extended 8 fect beyond the walls of the building on either side, forming concrete receiving and shipping platforms. All rooms, with the exception of the office and the milk-powder stornge room, were supplied with floor drains connected to the sewer.

The inside finish of the rooms consisted of a 5 -foot wainscoting of cement plaster over metal lathing extending around the base of the walls. Above this wainseoting the walls were finished with matched siding. Plaster board was nailed to the rafters to within 10 feet of the peak of the roof. At this point the plaster boarding was carried arross to the opposite rafters, forming a horizontal ceiling with an ail chamber above. The wainscoting was tinted a dark blue-gray, and the walls and ceiling were painted with white enamel over flat white. The inside of the refrigerators was painted with white enamel orer flat white. This color scheme proved to be practical and very pleasing in appearance.

The milk room and wash room were ventilated by means of five ventilators operated by natural draft. These ventilators extended through the roof into the air chamber, which, in turn, was provided with openings located directly under the ventilators.

\section{EQUIPMENT.}

On account of the experimental nature of the plant, the equipment was purchased with the irlea of acquiring units which could be rearranged at will, until a satisfactory layout was obtained. The milkhandling machinery, located in the milk room, consisted of a buttermilk machine of 300 gallons capacity; a milk pump; two 300 gallon

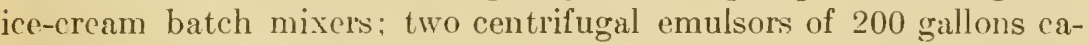
pacity cach, belt-driven from 2-horsepower motors; one tubular milk cooler of 5,000 pounds per hour capacity, composed of two sections, one for water and one for brine; an antifoam tank; a rotary bottle filler and capper; scales and tank for weighing water, and seales for weighing butter; a porcelain topped table for cutting butter; and a 
Babcock tester. 'The locations of these machines are given in Figures 1 and 2. All of this machinery, except the mixing and pasteurizing vats, emulsors, butter scales, and butter-cutting table, was located on the main floor. These machines were on the balcony, as shown in Figures 2, 3, and 4.

As it was necessary to start the construction of the building before all of the machinery had been selected, it was not possible to determine the headroom necessary to insure a gravity system from the mixing vats to the bottle filler. It was found necessary, therefore, to elevate the mixing vats about 2 feet above the floor of the balcony. They were supported on a stand made of 2 -inch pipe. This arrangement made speed in operation difficult and should be avoided. Figure 3 gives the elevation necessary for a gravity system.

All machines were connected with $1 \frac{1}{2}$-inch sanitary milk piping, and the valves and fittings were of the easily cleanable sanitary type. A no-foam can filler was installed between the antifoam tank and the bottle filler. All machines were driven by individual motors, thus doing away with the inconvenience of overhead shafting. The plant as designed was not equipped to manufacture ice cream, but when operations were started it was found necessary to manufacture a small amount of this product each day. A 60-quart continuous brine freezer was purchased but was never operated. In order to tide over until this machine was available for use, two of the old type can freezers were set up and operated. They were motor driven and were located under the balcony against the wall of the machinery room.

Bottles were washed with an automatic jet washer, having a capacity of approximately 4,000 bottles an hour. The pumps of this machine were operated by a direct-connected 10-horsepower motor. This washer was located in the center of the washing room and was oriented so that the bottles coming from the machine could be trucked directly into the milk room and stored. A small galvanizediron tank used for the washing of cans, which process was carried out by hand, together with a rinser and steamer, was located against the south wall of the washing room, as shown in Figure 1. A small brush washer, on which extremely dirty bottles could be scrubbed, was located on the north wall of the washing room. A two-effect water still with a capacity of 350 gallons per hour was located on the raised platform in the southwest corner of the washing room. The effluent pipe from this still projected through the wall into the milk room and discharged into a tin-lined distilled-water storage tank of 1,000 gallons capacity. This storage tank was connected by tinnedcovered piping to the suction end of the milk pump. At this point a three-way valve was located, so that fluid could be drawn from either the distilled water tank or the buttermilk machine as desired. 
The discharge from this pump was also arranged so that the effluent could be sent either into a weighing can mounted on a small platform near the skimmed-milk vat, or to the mixing vats on the balcony.

A small field laboratory for determining the bacteriological content of milk and milk products as well as the acidity and fat in milk, was located in the dressing-room. This laboratory will be described in the section on the analytical study of reconstructed milk products. A Babcock centrifuge was located on a stand on the balcony in the milk room, where frequent tests of the finished product could be conveniently made.

The refrigeration used for both the reconstructed milk plant and the cold-storage department of the commissary was furnished by a 15-ton refrigerating machine. The ammonia compressor was driven by a 30 -horsepower motor. All of the refrigerator rooms were cooled directly by the expansion of the compressed ammonia. Brine, cooled by the expansion of ammonia, was used for cooling the reconstructed milk. The brine was circulated by a steam-driven brine pump.

\section{WATER SUPPLY.}

The water used throughout the plant was obtained from the regular Nitro supply, which had previously been filtered and chlorinated. This water, brought into the building through a 3 -inch main, was used only for cleaning and cooling purposes.

STEAM SUPPLY

The steam used in the plant was generated in a central power plant located about 600 feet from the milk plant. It was brought to the plant by a 4 -inch steam main.

\section{Plant Operation.}

RECONSTRUCTED MILK PRODUCTS DEFINED.

As has been stated, reconstructed milk products are products made by the emulsification of butter fat in normal or reconstructed skimmed milk. Reconstructed skimmed milk may be made either by diluting unsweetened condensed or evaporated skimmed milk with distilled water or by dissolving dried skimmed milk powder in distilled water. The percentage of fat and solids not fat may be adjusted to suit the use which is to be made of the product, provided these percentages are plainly stated on the package. In the work described below skimmed milk powder was used exclusively as a source of solids not fat, and a high grade of unsalted butter as a source of butter fat. Reconstructed milk, reconstructed cream, ice-cream, and fermented milk products, such as cultured buttermilk and cottage cheese, were all manufactured. 
INGREDIENTS.

In the reconstruction of milk it should be borne in mind that no matter foreign to normal cow's milk should be added to the product. It is necessary, therefore, to use only the purest water, and the highest grade of dried skimmed milk and butter. The finished product can grade no higher than the ingredients used. The extreme importance of this point justifies a detailed discussion of each ingredient.

Water.-Nothing but the very purest of water, from both a chemical and bacteriological standpoint, should be used in the reconstruction of milk. Assuming that a normal water supply is available, which is free from all harmful bacteria, this water may contain mineral salts which might possibly be harmful to the weak digestion of an infant. For example, the hard waters of the Middle West and those containing a high percentage of sulphate could very easily cause intestinal disturbances in the young. Also, from the manufacturing standpoint, these salts would very probably have a deleterious eflect on the physical state of the emulsion. It is very probable that, in some districts, a very pure water, free from mincral constituents and free from all pollution might possibly be obtained, but this condition is so rare that only distilled water should be considered as a general source.

From a bacterial standpoint, water that is not absolutely free from pollution would be much more dangerous when used in milk than when used as water, for the growth of the harmful bacteria could easily take place in the excellent food medium which is furnished, and a very small number of pathogenic organisms gives rise to a number sufficient to be harmful. As the best of our filtered supplies may contain a small number of disease-producing organisms, practically all waters except those which have been freshly distilled are eliminated. It is, therefore, strongly recommended that no reconstructed milk products be manufactured without using water which is free from dissolved salts and pathogenic bacteria.

From a commercial standpoint it is highly important that the water used in the manufacture of milk products should be free from objectionable tastes, odors, sediment, and color. Even the characteristic flavor of poorly made distilled water may be easily distin - uished after the milk powder and butter have been added. This flavor also increases with the age of the milk and is decidedly objectionable in a product 24 to 48 hours old. In selecting a still for the manufacture of distilled water great importance should be placed on the ability of this still to produce a tasteless and odorless product.

Skimmed milk powder.-The skimmed milk powders available on the market to-day may be divided into three classes: Those made by drying on rolls at atmospheric pressure and a relatively high tempera- 
ture; those made by drying under reduced pressure and a correspondingly lower temperature; and those made by drying a finely atomized milk in a current of hot, dry air. The manufacturers of powder made by the various processes elaim advantages over powders made by other processes, and the purchaser must decide on the produet best suited to his needs.

In the manufacture of reconstructed milk, the following points are of extreme importance in the selection of a skimmed-milk powder:

The powder should be wholly and easily soluble in water and when reconstructed should give a solution with the characteristic flaror of normal skimmed milk.

The various constituents, such as the sugar, proteins, and mineral salts, should not have been altered during drying, and upon reconstruetion should appear in as near the original state as possible. A solution of the powder should have the power to hold an emulsion of butter fat similar to that found in normal milk.

As the reconstrueted milk must meet all the legal requirements of normal market milk, the original milk used for drying nust be produced in a cleanly fashion, and must meet all requirements of the local health department of the district where the reconstructed milk is to be sold. The process of drying should also be conducted in a cleanly manner, and rules prescribed for the handling of normal milk should be enforeed in the manufacture of the skimmed-milk powder. It is needless to say that this powder should contain only and all the ingredients oceurring in normal skimmed milk, with the exception of the water. Skimmed-milk powder is deliquescent and absorbs moisture rapidly. If the moisture content is high, the powder will lump in the containers and be unfit for use. It should therefore be stored in moisture-proof containers and should be sold with a guaranteed maximum moisture content.

Butter fat.- Sweet or unsalted butter is used as a source of butter fat. A good quality of sweet butter is almost as difficult to obtain as a good quality of skimmed milk powder or water. It should have good flavor, be free from pathogenic ormanisms, and be manufactured in such a manner that objectionable flavors and odors will not be produced in it during storage. It should never be artificially coloted, and manufacturers should guarantee the butter-fat content. The butter should be shipped in proper containers, and every container should be scored by the purchaser before it is accepted. Butter should be stored at a temperature sufficiently low to prevent the production of disagreeable flavors and odors and should be taken out of storage only as needed.

\section{Commercial Manufacture of Reconstructed Milk.}

RECONSTRUCTION OF SKIMMED MILK.

If the skimmed milk powder to be used has been selected with proper care the process of dissolving it is not a difficult one. At Nitro a val butcemilk machine of ordinary design was used for this 
purpose. This machine was of 300 gallons capacity and was equipped with a revolving heating coil to which blades were attached, serving simultaneously as agitator and heater. In selecting a vat, care should be taken to obtain one with a cylindrical bottom, and sides which are tangential to the surface of the cylinder. There should be no corners in which the undissolved powder may be pocketed. The necessary amount of distilled water should be placed in the vat and a weighed amount of skimmed milk powder added. The powder may be dumped in directly from the barrel, if care is taken to prevent foreign matter from falling from the sides of the barrel during the process. It was found that better results were obtained when the powder was removed from the barrel with a large sugar scoop. The coil agitator should be in operation while the powder is being added. The temperature of the water during the period of solution of the powder should be between $70^{\circ}$ and $80^{\circ} \mathrm{F}$.

Adding butter, and pasteurization.--After the complete solution of the powder had taken place, the skimmed milk was pumped to one of the mixing vats on the balcony. Here the necessary amount of butter, which had previously been cut into 4-inch cubes on the porcelain topped table provided for the purpose, was added, and the mixture brought to a temperature of $146^{\circ} \mathrm{F}$., and held there for 30 minutes. It was found that by the time the temperature had reached $146^{\circ} \mathrm{F}$. all the butter had melted. The holding time for the pasteurization of the skimmed-milk-butter mixture may therefore begin when the correct temperature is reached. It is necessary, however, to cut the butter into 4 -inch cubes or less if this procedure is to be followed.

Emulsifying the butterfat.--After the mixture had been pasteurized, and while it was at the pasteurizing temperature, it was passed through the centrifugal emulsors.

Emulsification is brought about by the forcing of the mixture of butter and skimmed milk through an extremely narrow opening, using centrifugal force generated by revolving the bowl of the emulsor at a speed of approximately 15,000 revolutions per minute.

Cooling.-From the emulsors the hot reconstructed milk was conducted to the upper trough of the cooler through sections of $1 \frac{1}{2}$-inch sanitary milk pipe to which had been attached small conductor heads. The milk from the emulsors contained a great deal of foam, and difficulty was experienced in transmitting this foaming product to the cooler. A large bank of foam collected where the milk entered the conductor head and also in the upper trough of the cooler. This necessitated the providing of ample capacity at both of these points to prevent the foam from accumulating and running over the edge of the conductor head and trough. For this reason it is felt that the use of an external cooler should be avoided in this process. The use 
of an external tubular cooler would eliminate to a great extent this waste and inconvenience. By inserting an antifoam tank, as described below, between the emulsor and the cooler, much of this trouble might be eliminated. This arrangement was not tried at Nitro, however.

1 proper regulation of the temperature of the milk as it leaves the cooler is an important point in the process of manufacture. As with ordinary milk, freezing throws the butterfat out of emulsion to a greater or less degreee. The flow of brine should therefore be regulated so that a minimum amount of milk freezes to the cooler. 111 milk which does so freeze should be re-emulsified before bottling. Satisfactory results can be obtained if the milk leaves the cooler at a temperature of from $40^{\circ}$ to $50^{\circ} \mathrm{F}$.

Foam removal.-As has been stated, the reconstructed milk as it leaves the emulsor contains a great deal of suspended air. This air is in such a finely divided state that it is eliminated slowly. Bottles filled with the milk directly from the cooler show, on two hours standing, an air space between the cap and the surface of the nilk varying from 1 inch to 3 inches in height. In order to eliminate this foam an antifoam

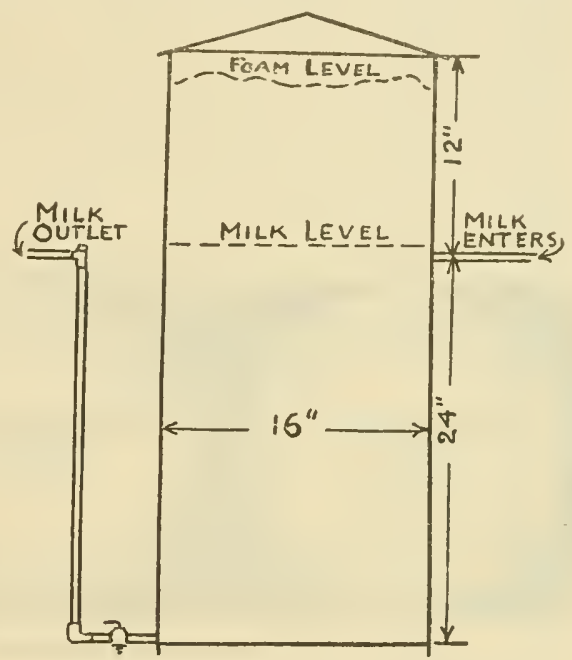

Fig. 6.-Section of antifoam tank used at the Reconstructed Milk Plant, Nitro, W. Va tank was inserted between the cooler and the can and bottle fillers. This foam tank is simply a detention tank, from the bottom of which the milk is drawn. A sketch of it is shown in Figure 6. With the emulsors running at full capacity (approximately 400 gallons per hour) this tank gave a detention time of approximately $3 \frac{1}{4}$ minutes. This arrangement eliminated practically all the foam from the milk.

Filling containers.-From the foam tank the milk passed into a rotary bottle filler. A "no foam" can filler was inserted between the antifoam tank and the bottler. At this point all the cans were filled. The bottle filler was driven by a direct-connected motor and had a capacity sufficient to handle the eflluent from the emulsors. This type of filler and capper has a decided advantage over a case filler in that all bottles have to be handled twice and therefore get two inspections. When using the case filler there is a great tendency to slight the bottle inspection, and many damaged bottles which 
should not be used are filled and put into circulation. The bottles used were of the ordinary glass, common-sense type, capped with paper caps. As is customary, the caps bore the package label.

Storage.-Immediately after the containers were filled they were trucked into the cold-storage room, where they remained until delivered. The temperature of this room was approximately $33^{\circ} \mathrm{F}$.

Labeting.-Regulations pertaining to all foodstuffs should be applied to reconstructed milk products. These products should be sold only for what they are and only when the packages are properly labeled. According to the present law, a milk made from skimmed milk powder, water, and butter is not "milk," and should not be sold as such. The law distinctly states that milk is the normal fluid secreted by the mammary glands of the cow, and a product which has been reconstructed certainly can not be classed as "milk."

In choosing a name for this product various titles have been considered. From the list has been chosen the term "reconstructed milk." It is felt that this is fully descriptive and leaves no reason

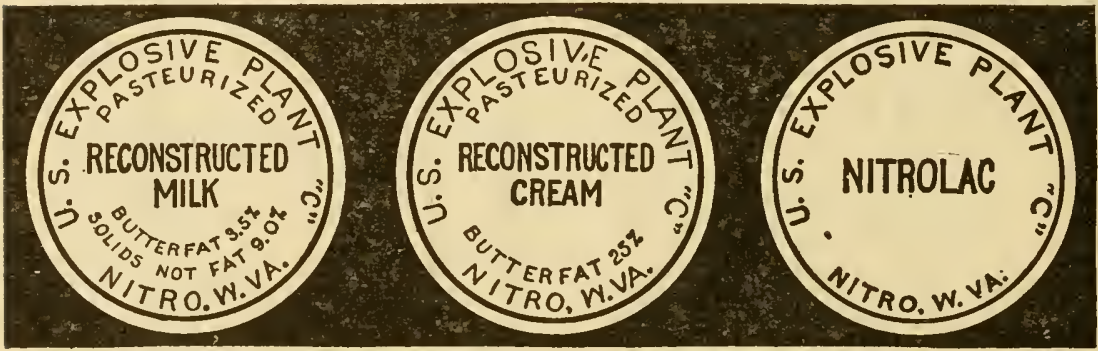

FIG. 7.-Bottle caps used at the Reconstructed Milk Plant, Nitro, W. Va.

for doubt as to the product. The word "reconstructed" may possibly arouse some sense of fear in the minds of the unenlightened consumer, for it may signify to him a product which has been at some time in an unsatisfactory condition and later renovated. Various other names which have been suggested are "remade," "emulsified," "reconstituted," "recombined," and "rehydrated." Any of these terms may be used, subject to the approval of the officials who are intrusted with the enforcement of the pure-food laws.

In labeling any of these manufactured products the word "reconstructed," or any other similar word which may be used, should be given as much prominence as the word "mill." The label should also set forth the percentage of butter fat and the percentage of milk solids not fat which the product contains. Figure 7 shows samples of the various caps used at Nitro. The reconstructed milk manufactured there contained 9 per cent millk solids not fat and $3 \frac{1}{2}$ per cent butter fat. The cream contained 25 per cent butter fat. $\Lambda$ form of fermented milk similar to buttermilk was manufactured and styled 
"Nitrolac." It was not considered proper to label this milk buttermilk, for the term "buttermilk" has a distinct meaning. It is a product of the churning of milk or cream and the name should bo used for no other product. The fermented milk used at Nitro was simply a cultured milk of a low percentage butter fat.

Washing containers.-All containers were washed in the room provided for that purpose. The bottles were inverted and washed in the cases. The washer used consisted of a series of tanks from which water or alkali solutions were pumped with considerable pressure through a series of jets. The cases were intermittently advanced by a mechanical device and the jets so arranged that during the resting period a powerful stream of water or chemical solution was injected into each bottle while a number of streams were forced against the outside and inside of the case. The temperature of the first rinse water was approxinately $110^{\circ} \mathrm{F}$., a temperature sufficient to warm the cold bottle without danger of breaking it. The temperatures of the subsequent washing and rinsing solutions were so regulated that the final temperature of the bottle was approximately that of boiling water. Before leaving the machine each bottle was subjected to a jet of live steam which acted as the final sterilizing agent.

All cans and metal containers were washed by hand in a galranized iron tub prorided for the purpose. After a thorough brushing with an alkali sutution, the can and cover were inverted over a can rinser and sterilizer where they received a hot-water rinse and a thorough steaming.

Cleaning mith-handling machinery.-At the end of each day's run all milk-handling machinery and piping were completely disassembled, rinsed with warm water, scrubbed with a brush and hot alkali solution, rinsed with hot water, and then sterilized by blowing lire steam into or through them for a considerable time. The machinery was then partially assembled. In the morning before operations commenced, the machinery was completely assembled and connected at various points to the steam line. Steam was blown through the assembled machinery for approximately 20 minutes. This produced a satisfactory sterilization.

The most difficult picce of machinery to sterilize was the tubular cooler. This is the general experience where this type of cooler is used. At the end of the run the tubes are full of water or brine, and the ordinary methods of steaming are not sufficient to heat the whole mass up to the sterilizing point. Satiffactory sterilization may be accomplished by emptying the tubes and either blowing steam, under pressure, through them, or by inserting a steam hose between the covers and the cooler and allowing steam to blow in for some time. If either of these methods is used, a by-pass around the brine pump must be supplied so as to drain the brine coil back to the tank without 
wasting the brine. These methods of sterilization are very likely to cause leaks in the cooler, owing to the uneren expansion of the coils. It was found at Nitro that satisfactory sterilization could be accomplished by a thorough brushing with soda solution and then rinsing with approximately 200 gallons of water which had been previously heated to about $180^{\circ} \mathrm{F}$. in one of the pasteurizing rats. From a bacteriological standpoint this method is not as efficient as draining the coils and applying steam.

QUANTITY OF THE RECONSTRUCTED PRODUCTS MANUFACTURED.

As has been stated, the plant had a capacity of at least 2,000 gallons of reconstructed products in an eight-hour day. This amount of milk was never sold in Nitro, owing to the impossibility of proper delivery. Nitro was never completely finished, and the streets, up to the cessation of operations, were in such poor condition that a house-to-house delivery could not be made. It was intended to substitute for this retail delivery a wholesale delivery to a number of small distributing stations centrally located, where the rarious milk products could be purchased by the consumer and carried to the homes. This system would have had the adrantage of eliminating bottle loss. Unfortunately, these milk stations were not finished in time to take care of the rush. The fact that milk could be purchased only at the general stores cut the consumption greatly.

Table I gives the daily quantities of the various products manufactured during the months of September, October, November, and December, 1918, and part of January, 1919.

TABLE I.-Quantity of reconsiructed milk products manufactured daily at Nitro, $W$. Va., during September, October, November, and December, 1918, and part of Januar?, 1919.

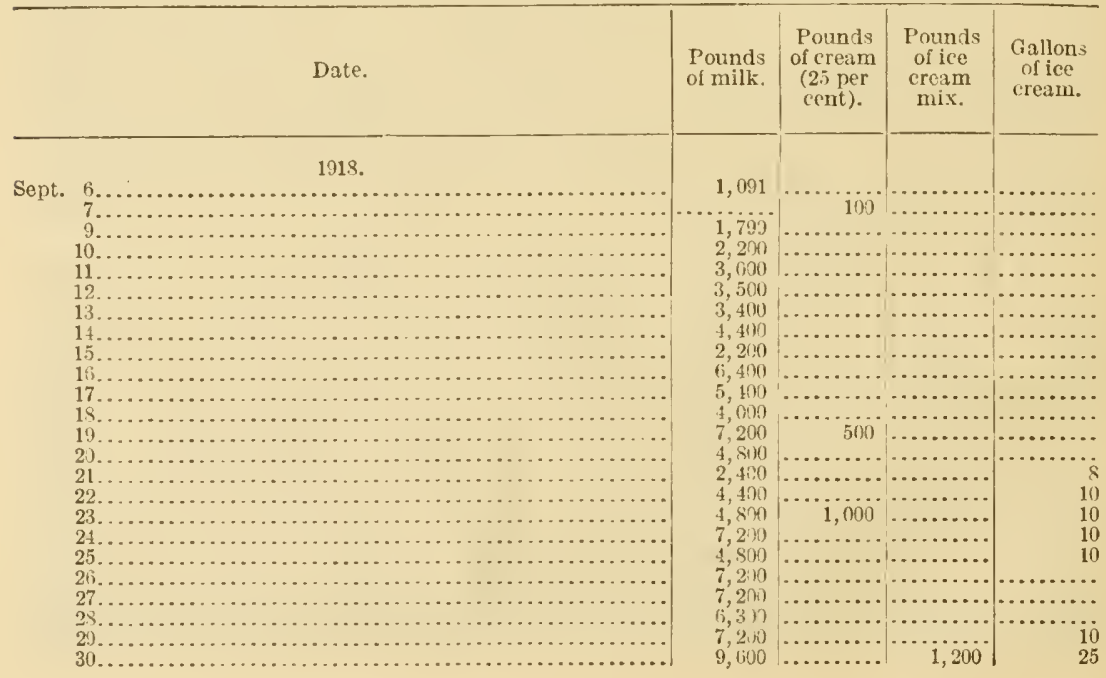


TABLE I.-Quantity of reconstructed milk products manufactured daily at Nitro, IT. Ta., during September, October, November, and December, 1918, and part of January, 1919Continued.

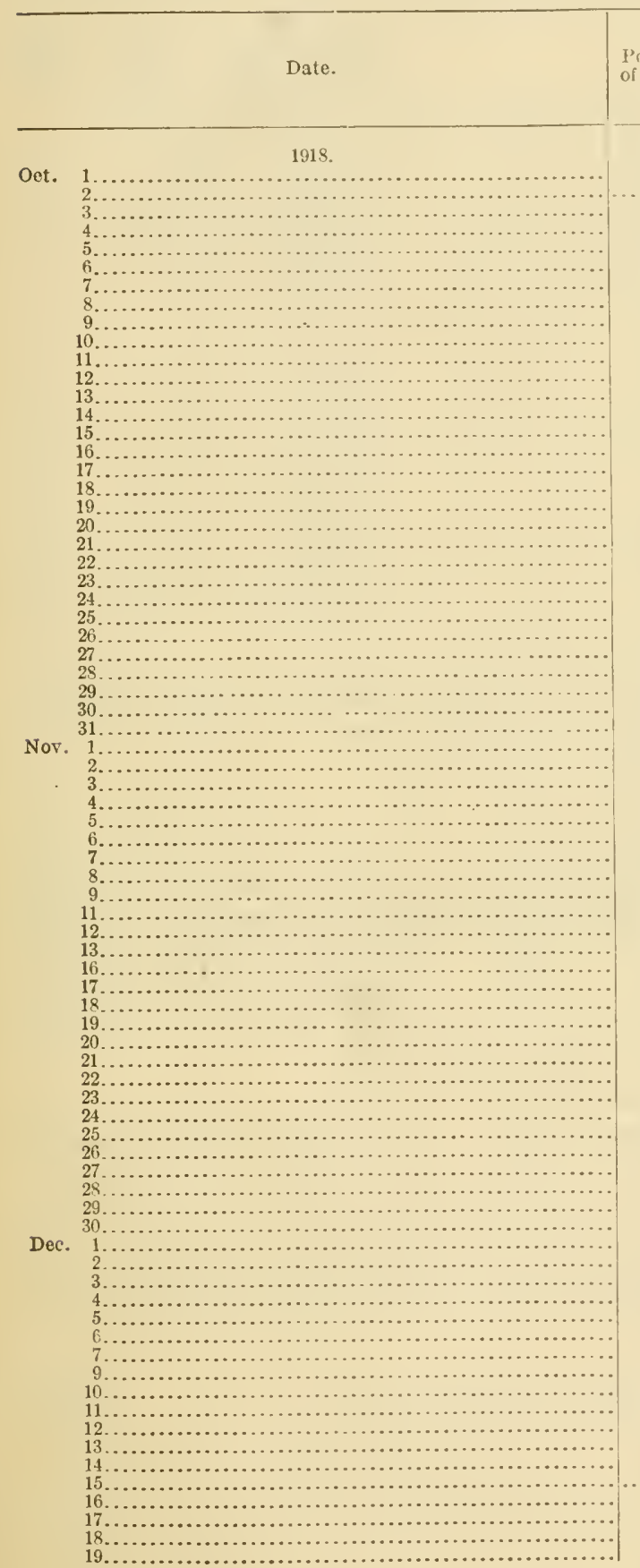

\begin{tabular}{|c|c|c|c|}
\hline $20 i$ & & & 125 \\
\hline $7,2, k)$ & $(i 0)$ & 1,200 & $\begin{array}{l}50) \\
55\end{array}$ \\
\hline 7,200 & & 1,210 & 115 \\
\hline $\begin{array}{l}7,290 \\
7,200\end{array}$ & & & $\begin{array}{l}145 \\
130\end{array}$ \\
\hline 7,200 & & 1,200 & $\begin{array}{l}130 \\
125\end{array}$ \\
\hline 7,200 & & & 95 \\
\hline 7,200 & & & 85 \\
\hline $\begin{array}{l}7,210 \\
7,210\end{array}$ & 500 & 1,200 & 75 \\
\hline 7,200 & & 1,200 & $\begin{array}{r}135 \\
65\end{array}$ \\
\hline 7,270 & 590 & & 110 \\
\hline 7,2$) 0$ & & & 125 \\
\hline $\begin{array}{l}7,200 \\
7,200\end{array}$ & & 1,200 & 115 \\
\hline 7,200 & & $200^{\circ}$ & $\begin{array}{l}110 \\
145\end{array}$ \\
\hline 8,100 & & & $\begin{array}{r}145 \\
75\end{array}$ \\
\hline $7,2 m$ & & & 85 \\
\hline 7,27 & & 1,200 & 125 \\
\hline $\begin{array}{l}8,4100 \\
8,400\end{array}$ & & & $\begin{array}{l}90 \\
65\end{array}$ \\
\hline 8,400 & & 1,200 & 110 \\
\hline 8,400 & & & \\
\hline $\begin{array}{l}9,600 \\
8,400\end{array}$ & & 1,200 & $\begin{array}{r}110 \\
40\end{array}$ \\
\hline $\begin{array}{l}8,400 \\
8,400\end{array}$ & & 600 & $\begin{array}{r}40 \\
120\end{array}$ \\
\hline 9,600 & 500 & & $\begin{array}{l}120 \\
150\end{array}$ \\
\hline $\begin{array}{l}9,600 \\
7,200\end{array}$ & 500 & & 35 \\
\hline $\begin{array}{l}7,200 \\
8,400\end{array}$ & & & $\cdot$ \\
\hline $\begin{array}{l}8,400 \\
7,200\end{array}$ & & & ... \\
\hline $\begin{array}{l}7,20101 \\
7,200\end{array}$ & & & \\
\hline 8,490 & & & 81 \\
\hline 8,400 & 500 & & 85 \\
\hline 7,200 & & 600 & 40 \\
\hline $\begin{array}{l}8,400 \\
8,400\end{array}$ & & & 40 \\
\hline $\begin{array}{l}7,290 \\
7,290\end{array}$ & $\cdots$ & 600 & \\
\hline 12,000 & & & 100 \\
\hline $9, \operatorname{lin} 0$ & & 1,200 & 30 \\
\hline $\begin{array}{l}8,400 \\
7,200\end{array}$ & & & \\
\hline 12,800 & & 1,200 & 75 \\
\hline 4, 500 & & & is \\
\hline $\begin{array}{l}4,800 \\
7,200\end{array}$ & & & $\begin{array}{r}105 \\
25\end{array}$ \\
\hline 4,800 & $\cdots$ & $\cdots \quad 1,200$ & $\begin{array}{l}2 \\
2\end{array}$ \\
\hline 4,800 & 500 & ........ & 9 \\
\hline 270 & $\cdots \cdots$ & & 7 \\
\hline 800 & $\cdots \cdots$ & & 3 \\
\hline $\begin{array}{l}4,800 \\
2,400\end{array}$ & $\cdots$ & & \\
\hline 4,800 & & 1,200 & \\
\hline 4,800 & 500 & & 7 \\
\hline $\begin{array}{l}4,800 \\
4,800\end{array}$ & $\cdots$ & & \\
\hline 4,860 & & 1,200 & 5 \\
\hline 4,800$)$ & & & 5 \\
\hline $\begin{array}{l}2,400 \\
4,800\end{array}$ & 500 & $i, 2 m 0^{\circ}$ & \\
\hline $\begin{array}{l}4, x(0) \\
2,-400\end{array}$ & $\ldots$ & 1,200 & \\
\hline $2,4 n$ & & $\cdots$ & \\
\hline $4,8(10)$ & & & $\begin{array}{r}65 \\
35 \\
150\end{array}$ \\
\hline $\begin{array}{l}2,400 \\
7,200\end{array}$ & $5 ! \cdots)$ & 1.200 & 150 \\
\hline 2,400 & $\cdots$ & $\begin{array}{l}1,200 \\
\ldots \ldots\end{array}$ & \\
\hline 2,400 & ... & $\because$ & \\
\hline $4, \div:(1)$ & & & \\
\hline,$(4)$ & 500 & & \\
\hline$(5,00)$ & & & \\
\hline & & & \\
\hline & 500 & & \\
\hline & ......... & $\begin{array}{l}1,200 \\
1,200\end{array}$ & \\
\hline & & & \\
\hline
\end{tabular}


TABLE I.-Quantity of reconstructed milk products manufactured daily at Nitro, W. Va., during September, October, November, and December, 1918, and part of January, 1919Continued.

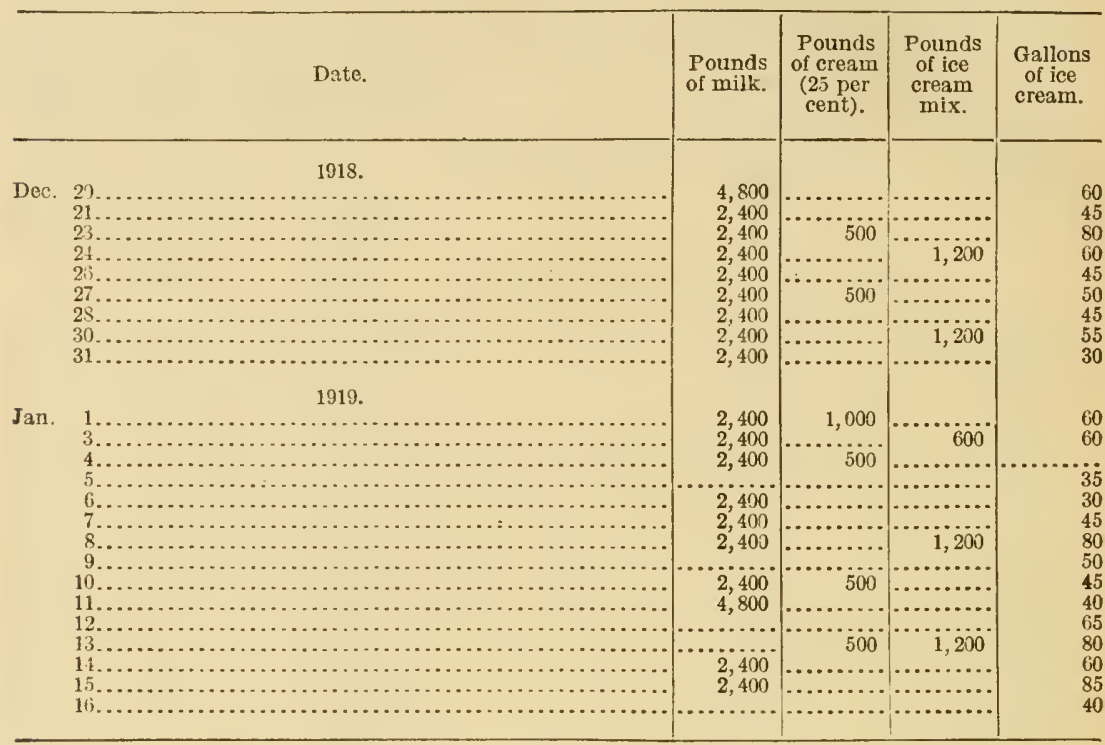

The quantities of milk and cream produced are large enough to serve as a basis for economic considerations.

\section{OPERATING SChEDULE.}

It was expected that full data on the cost of operation of this plant could be collected by keeping accurate labor charts and metering the electric power, the water, and the steam consumed by each machine. Unfortunately the meters were lost in transit, due to congested traffic conditions, and this part of the data is not available. Time sheets of the various operations were kept, and the operating schedule given below was computed from them.

The capacity of the plant depends on the time required to mix the ingredients and pasteurize them. It is therefore of first importance to determine the time required for the various operations connected with this part of the process. Accurate time sheets were kept for two months, and it was found that the following time intervals were required to perform the rarious operations included in the mixing, pasteurizing, and emulsifying of one batch, 282 gallons, of milk:

Weighing and transferring water and skimmed milk powder to vat....................... 33

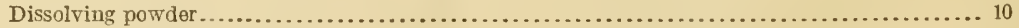

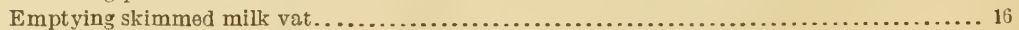

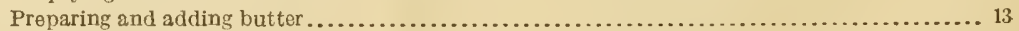

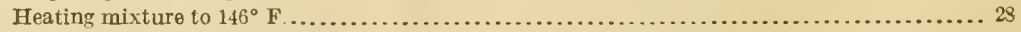

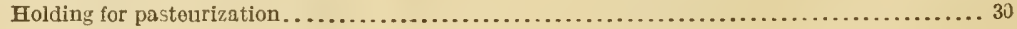

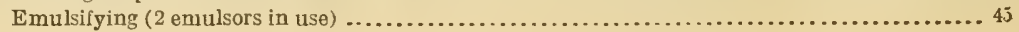


Using these data, a daily schedule of operation of the three rats and two emulsors was planned. This schedule is giren in T'able II. Vats $A$ and $B$ represent the mixing and pasteurizing rats on the balcony, and vat $\mathrm{S}$ is the skimmed milk rat located on the main floor.

It will be noted from Table II that vat $\mathrm{S}$ is in continuous operation, but that vats $A$ and $B$ are idle 20 minutes, and the emulsors 15 minutes, between erery two batches. This loss of time could be eliminated by changing the method of preparing the skimmed milk. Too much time is consumed in measuring and handling the water and powder. 'This time can be reduced by arranging the building so that the powder storage room and the distilled water storage tank are on the same level with the present balcony. A weighed charge of powder could then be dumped directly into a hopper placed above the skimmed milk rat while the powder in the prerious batch is dissolving. If, at the same time, water from the elevated tank could be run directly into the mixing vat through a 4 -inch conductor, the time of charging the vat could be reduced to approximately 10 minutes. An ordinary gauge glass attached to the end of the rat, extending the full height of the vat, could be calibrated accurately enough to provide means of measuring the distilled water. By using this arrangement of measuring devices and by having the man responsible for the mixing of the skimmed milk commence work an hour ahead of the rest of the force, the output of the plant can be increased from six to eight batches per day. Such an arrangement is outlined in Table III.

It will be noted that between Batches II and III, IV and V, and VI and VII there are 12-minute intervals during which no milk is passing through the emulsors. These delays are unavoidable when vats of this capacity are used. 


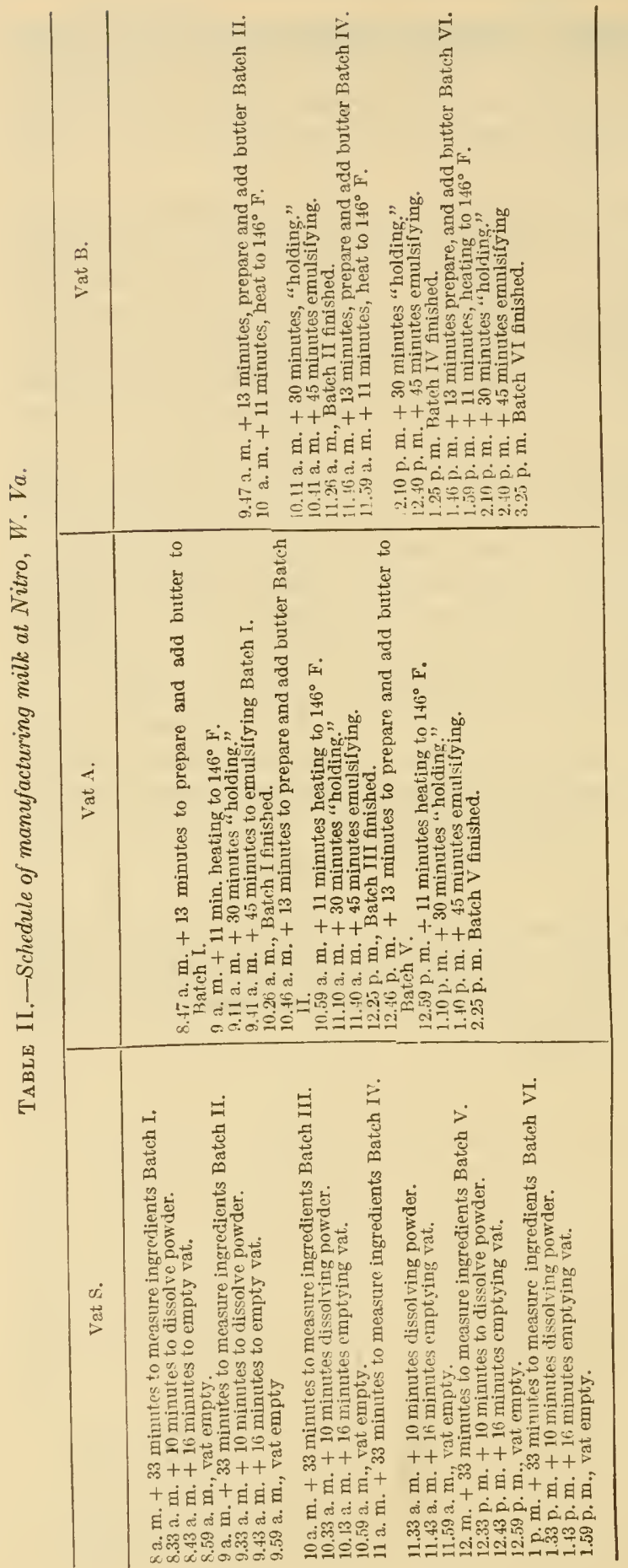




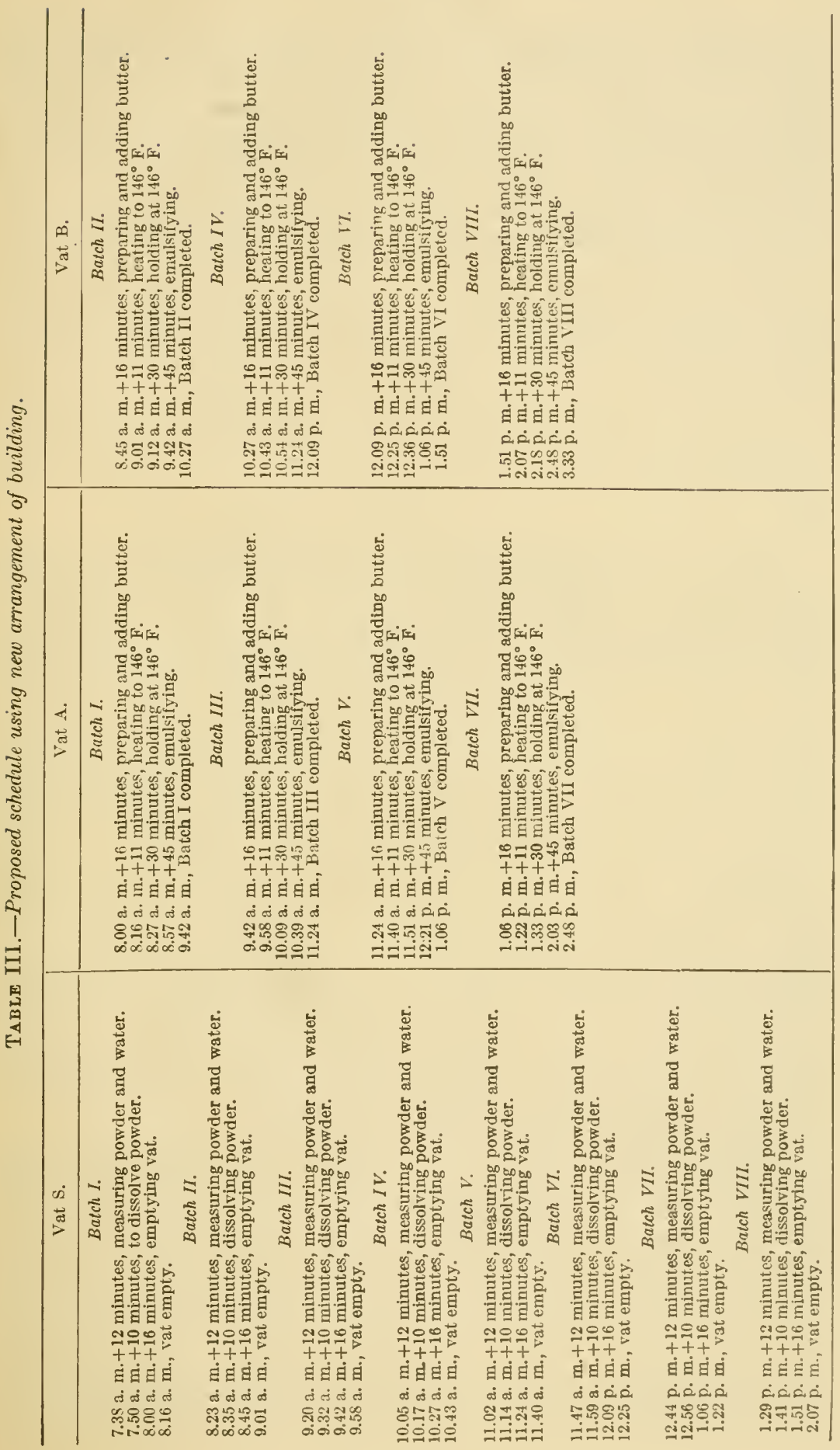


OPERATING FORCE.

A plant as described can be operated with a force of seven men. This force should consist of a foreman, who would have general charge of the plant and would personally operate the skimmed milk vat; an assistant foreman, who would spend his entire time on the balcony level, operating the pasteurizers and emulsors; three men operating the bottling and capping machine-one man feeding the machine with empties, one man removing the filled bottles, and one man handling the cases of empty and filled bottles-one man trucking the filled cans to the refrigerator, and one man operating the refrigerating machine and assisting as his time permits at any temporary point of congestion. "The foreman and assistant foreman should be men skilled in the handling of milk and the operation of milk machinery, and the engineer should, of course, understand the operation of a refrigerating machine. The other employees may be of a good grade of laborers.

\section{COST OF PRODUCING BOTTLED RECONSTRUCTED MILK.}

The cost of producing bottled reconstructed milk will vary with the locality and with the market price of the various commodities used in the manufacture and handling of the product; therefore, no exact figures can be given. It can be stated, however, that the cost of a plant to manufacture reconstructed milk, and the number of men and the amount of power necessary to operate it, are no greater than similar items in the operation of an ordinary modern pasteurizing and bottling plant, and therefore, the cost of manufacturing and bottling reconstructed milk is approximately the same as the plant charge for pasteurizing and bottling fluid milk. The delivery charge is, of course, identical in both cases. The economic advantage gained by drying the skimmed milk and manufacturing butter at the point of production and recoustructing the milk at the point of consumption, rather than handling it in the normal fluid state, lies in the difference in price between sweet fluid milk delivered in bulk at the pasteurizing and bottling plant, and powder, butter, and water delivered at the same location, plus the economic advantage gained by always having the supply equal the demand.

Skimmed milk powder at the present time is manufactured in the great dairy regions of New York, Pennsylvania, Ohio, Indiana, Illinois, Michigan, Wisconsin, Minnesota, and on the west coast. Sweet butter is also manufactured in quantity in these States. Distilled water can be produced locally. The prices of powder and butter are necessarily the market prices at the point of manufacture, plus the freight charges. During the past year (1919) the market price of skimmed milk powder at the factories has varied in carload lots from 20 cents to 26 cents per pound. Sweet butter has varied on the New York market from 46 cents to 71 cents per pound. Distilled water 
can be made for less than one-quarter of a cent per gallon. Using these figures, the cost of the ingredients entering into a quart of milk containing 9 per cent solids not fat and 3.5 per cent fat will vary from 7.9 cents to 13.3 cents. To this must be added the freight on the powder and butter, which is a minor item. The price paid the producers in the South, during this period, for normal fluid milk has varied from 10 cents to 20 cents per quart, depending on the locality. It is certain, therefore, that in these sections reconstructed milk can be sold for a lower price than normal milk.

Whether reconstructed milk is more economical for a given community than normal fluid milk can only be determined by a careful comparison of the prices of the raw commodities delivered at the point of consumption.

If all the milk produced in the country could be dehydrated and subsequently reconstructed as needed to meet the demand, there is little doubt that a great financial saving to the country at large would result. Until such method is universally adopted a careful study of the local conditions of each community must be made before deciding on the correct method of milk handling.

From a bacterial standpoint reconstructed milk has deciled adrantages over market milk of good quality, as will be shown in the section on the bacteriology of this product.

THE QUALITY OF THE FINAL PRODUCT.

The manufacture of milk powder and reconstructed milk is in its infancy. The processes have been studied to some extent, but little is known regarding the effect of the various methods of drying and reconstructing on the composition of the finished product. Infant feeding experiments have been conducted in England, in which dried milk powder was used. These experiments are reported in Food Reports No. 24 to the local government board on Public Health and Medical Subjects, New Sories No. 116. ${ }^{2}$ These experiments indicate that children can be raised on reconstructed milk with no more difficulty than on normal cows' milk.

To the casual adult drinker of milk, carefully produced reconstructed milk made from the better grade of powders available in quantity on the market to-day, has the appearance of normal milk, except that it lacks a cream line. It has a flavor slightly moro "cooked" than the pasteurized market milk. This flavor to nuny observers gives the impression of excessive "richness." It is not objectionable to those used to pasteurized milk, but is somewhat distrasteful to those accustomed to drinking raw milk. The freshly made product very ensily passes for first-cliss noimal milk. One seious physical defect exists, however: the fat emulsion as produced

${ }^{2}$ See also "Dried Milk Powder in Infant Feeding: Safety, Usefulness, and Comparative Value-A Preliminary Report," by W. H. Price, Surgeon(R.), United States I'ublic IIeallh Service, I'ublic IIealth Reports, vol. 35, No. I4, A pr. 2, 1920, pp. SU9-S2S.-Evitok. 
at Nitro is not wholly permanent. On standing for 48 hours at a temperature approximately $35^{\circ} \mathrm{F}$. or for 20 hours at room temperature, a thin crust of butter forms on the top of the fluid. If the milk is kept in an ordinary refrigerator and consumed within 24 hours no separation is noticed. This "buttering" in all probability is caused by some change in the complex ingredients of the skimmed milk brought about by the drying process. The power to hold fat in emulsion has been partially destroyed. As soon as this effect is overcome by the manufacturers, a product will be available which will readily compete with normal fluid milk. At present, reconstructed milk forms an excellent emergency supply which may readily take the place of normal milk during a shortage of the latter product.

\section{Summary.}

1. Reconstructed milk and cream made from skimmed milk powder, unsalted butter, and water have been produced in large quantities at Nitro, W. Va., and sold to the public.

2. The cost of manufacturing these products in the Southern States is less than the cost of local normal milk. As the distance between the points of efficient production and consumption is lessened, this difference in cost becomes less. In the dairy sections at the present time fluid milk can be sold more cheaply than reconstructed milk.

3. Reconstructed milk products serve as excellent emergency supplies, and as soon as the process of manufacturing milk powder is perfected they will no doubt compete in the open market with normal milk products.

\section{Acknowledgments.}

The authors wish to express their appreciation of the valuable assistance given them throughout this demonstration by Passed Asst. Surg. J. A. Watkins, of the United States Public Health Service, resident officer in charge of the department of medical relief and sanitation of Nitro; Mr. Hugh C. Leighton, executive officer of the Nitro commissary department; Mr. C. S. Bassett; Mr. L. C. Johnson; Mr. R. G. Soule; and all others who through suggestions or material aid helped in making the demonstration a success.

\section{AN ANALYTICAL STUDY OF RECONSTRUCTED MILK.}

By Albert F. Stevenson, Sanitary Engineer, and C. P. RhynUs, Assistant Sanitary Engineer, United States Public Health Service.

Before any process devised for the handling of milk can be pronounced a success, an analytical study of the product, both from a bacteriological and chemical standpoint, must be made. If this study shows the product to be materially altered or to be a potential source of danger, from a health standpoint, the process is valueless.

It was therefore of the greatest importance to determine in this plant, the initial one producing reconstructed milk on a commercial 
scale, whether the product was of a high or low grade, from a bacterial and chemical standpoint.

A plant laboratory was installed where bacteriological analyses could be made. It was possible by this means to check the plant operation and to determine, at all times, the quality of the product which was being sold. As is always the case, the field laboratory proved one of the most important assets of the plant. Samples of the finished product as well as samples from the various stages of the process of manufacture were analyzed daily. The finished product was again sampled and analyzed, after delivery, by the division of health and sanitation of the Nitro organization. These last analyses correspond to those which would be made by the board of health of an ordinary community.

The methods employed in making bacteriological analyses were those recommended by the committee on standard methods of milk analysis of the American Public Health Association. Samples were collected from the various stages of the process of manufacture, in glass test tubes plugged with nonabsorbent cotton. Filled pint bottles, selected at different periods during the day, served as bottled milk samples. These samples were refrigerated until the actual analysis was made, which occurred, generally, within two hours of the time of sampling. 'The culture media used for the bacteriological analysis were made at the Hygienic Laboratory in Washington, D. C., and shipped to Nitro in tin containers. The media were transferred from the cans to 4-ounce glass bottles, after arriving at the plant, and were then resterilized. A check titration was always made on each shipment of media, after the final sterilization in the glass bottles. Sterilization of media was accomplished by heating for one hour at $100^{\circ} \mathrm{C}$. in an Arnold sterilizer for three consecutive days, and then incubating the media for 24 hours to throw out any contaminated bottles. The dilution water was sterilized in the same manner. Dry sterilization was accomplished in the oven of an ordinary gas stove. Forty-cighthour $37^{\circ} \mathrm{C}$. total counts were made on the various samples. No attempt was made to isolate any particular organism.

The results of the bacteriological determinations made on the finished reconstructed milk in the final containers are given in Table IV. Table $\mathrm{V}$ shows the results of arranging these counts in the order of magnitude. Serenty-five per cent of them were 5,000 or less. The highest count obtainer was 55,000, and only three times was a count over 30,000 obtained.

Total counts made on the bottled milk by the department of sanitation are given in Table VI. Rearrangement of these counts in the order of magnitude, as shown in Table VII, emphasizes the fact that 15 per cent of them are under 1,000 and 97 per cent are under 5,000 . Only one count out of the total 33 was greater than 5,000 . 
A bacteriological study of the manufacturing process brought out some useful information. Table VIII gives the number of bacteria present in reconstructed skimmed milk. These figures, of course, include both the number of bacteria in the water and in the milk powder.

TABLE IV.-Bacterial content of finished product in container.

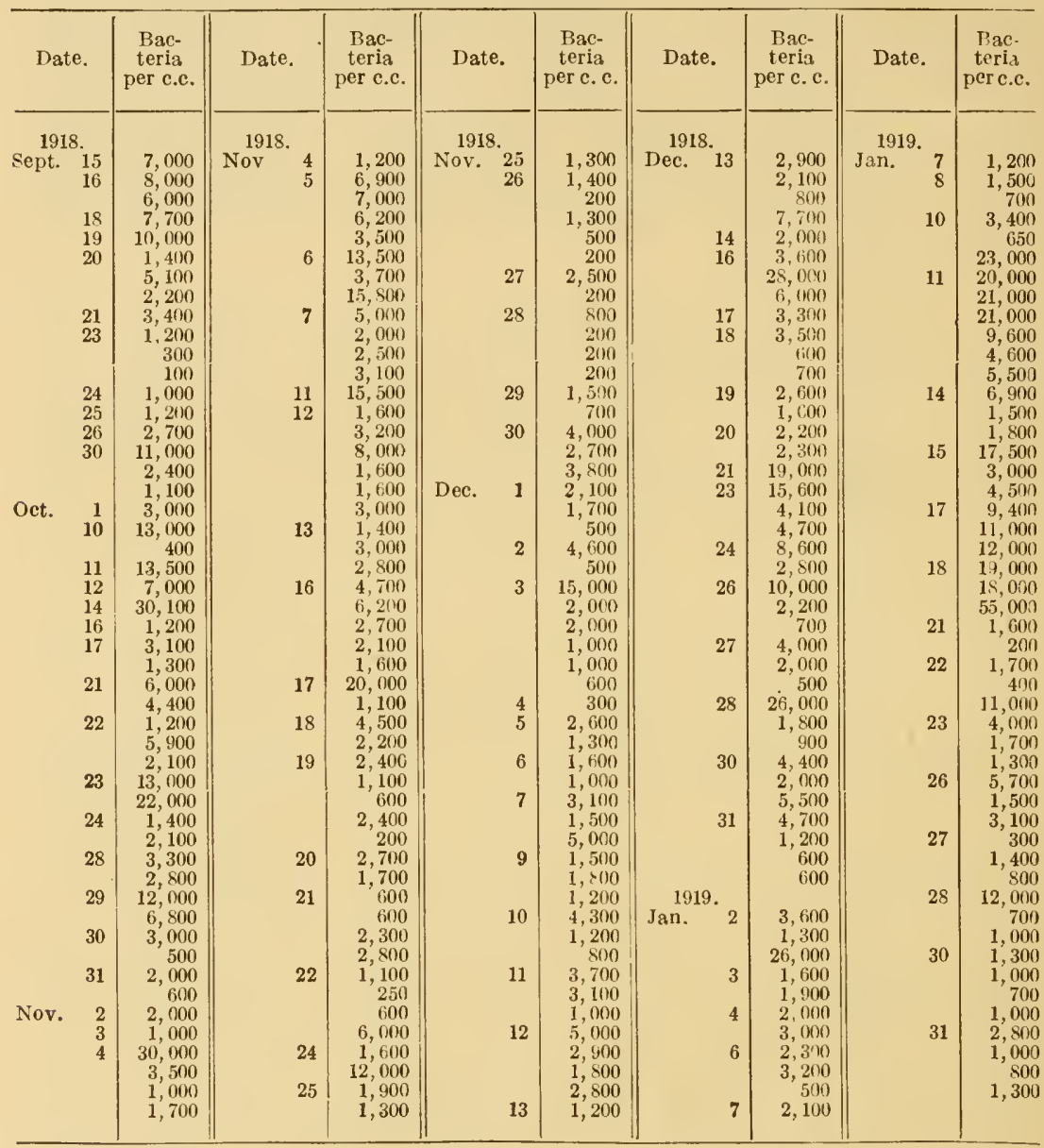

TABLE V.-Results of arranging bacteriological counts of bottled milk according to magnitude.

\begin{tabular}{|c|c|c|c|c|c|}
\hline Range of counts. & $\begin{array}{l}\text { Number } \\
\text { of counts } \\
\text { within } \\
\text { range. }\end{array}$ & $\begin{array}{l}\text { Per cent } \\
\text { of counts } \\
\text { within } \\
\text { range. }\end{array}$ & Range of counts. & $\begin{array}{c}\text { Number } \\
\text { of counts } \\
\text { within } \\
\text { range. }\end{array}$ & $\begin{array}{l}\text { Per cent } \\
\text { of counts } \\
\text { within } \\
\text { range. }\end{array}$ \\
\hline \multirow[t]{2}{*}{ 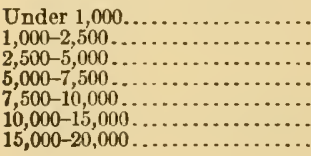 } & \multirow[t]{2}{*}{$\begin{array}{r}43 \\
91 \\
54 \\
20 \\
7 \\
13 \\
8\end{array}$} & \multirow[t]{2}{*}{$\begin{array}{r}17.4 \\
36.6 \\
21.8 \\
8.1 \\
2.8 \\
5.3 \\
3.2\end{array}$} & \multirow[t]{2}{*}{ 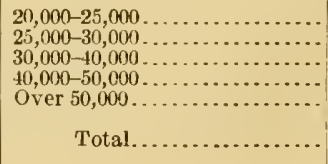 } & $\begin{array}{l}6 \\
3 \\
2 \\
0 \\
1\end{array}$ & $\begin{array}{l}2.4 \\
1.2 \\
0.5 \\
0.0 \\
0.4\end{array}$ \\
\hline & & & & 248 & 100.0 \\
\hline
\end{tabular}


TABLE VI.-Bacteriological examinations of reconstructed milk made by the Sanitary Division, Nitro, W. Va.

\begin{tabular}{|c|c|c|c|c|c|}
\hline Date. & Source. & $\begin{array}{l}\text { Bacteria } \\
\text { per c. c. }\end{array}$ & Date. & Sourcc. & $\begin{array}{l}\text { Bacteria } \\
\text { perc.c. }\end{array}$ \\
\hline $\begin{array}{r}1918 . \\
\text { Sept. } 23 \\
24 \\
25 \\
26 \\
27 \\
28 \\
30 \\
\text { Oct. } 1 \\
2 \\
3 \\
4 \\
4 \\
5 \\
\text { Nov. } 11 \\
12 \\
13 \\
14 \\
15 \\
16\end{array}$ & 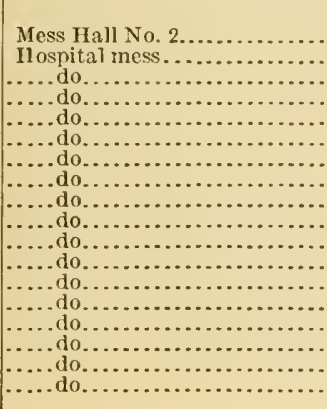 & $\begin{array}{l}2,000 \\
1,650 \\
2,350 \\
2,150 \\
2,000 \\
1,950 \\
8,600 \\
1,950 \\
2,600 \\
2,900 \\
2,700 \\
2,850 \\
900 \\
2,500 \\
1,500 \\
1,400 \\
700 \\
1,800\end{array}$ & $\begin{aligned} 1918 . \\
\text { Dec. } 16 \\
17 \\
19 \\
20 \\
21 \\
23 \\
21 \\
26 \\
27 \\
28 \\
31 \\
\text { Jan. } \\
\text { J919. } \\
1 \\
2 \\
3 \\
4\end{aligned}$ & 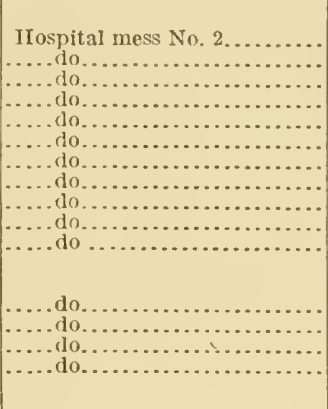 & $\begin{array}{r}200 \\
580 \\
1,550 \\
1,000 \\
1,900 \\
2,150 \\
1,(600 \\
2,100 \\
2,450 \\
2,000 \\
2,800\end{array}$ \\
\hline
\end{tabular}

TABLE VII.-Results of rearranging the bacteriological analyses made on the bottled milk by the Sanitary Division, Nitro, W. Va.

\begin{tabular}{|c|c|c|}
\hline Range of counts. & $\begin{array}{l}\text { Number } \\
\text { of eounts } \\
\text { within } \\
\text { range. }\end{array}$ & $\begin{array}{l}\text { Per cent } \\
\text { of counts } \\
\text { within } \\
\text { range. }\end{array}$ \\
\hline 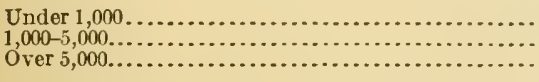 & $\begin{array}{r}5 \\
27 \\
1\end{array}$ & $\begin{array}{r}15 \\
82 \\
3\end{array}$ \\
\hline 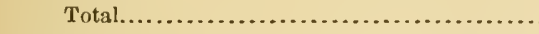 & 33 & 100 \\
\hline
\end{tabular}

TABLE VIII.-Bacterial content of reconstructed skimmed milk.

\begin{tabular}{|c|c|c|c|}
\hline Date. & $\begin{array}{c}\text { Bacteria } \\
\text { per cc. }\end{array}$ & Date. & $\begin{array}{c}\text { Bacteria } \\
\text { per cc. }\end{array}$ \\
\hline 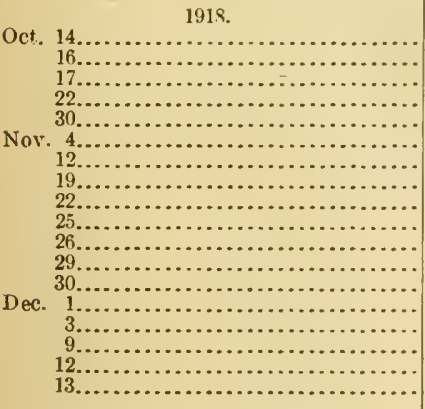 & $\begin{array}{r}17,400 \\
61,000 \\
113,000 \\
27,600 \\
4,200 \\
7,800 \\
5,700 \\
5,300 \\
15,000 \\
6,700 \\
9,000 \\
24,400 \\
41,200 \\
61,00 \\
43,000 \\
27,400 \\
39,000 \\
22,000\end{array}$ & 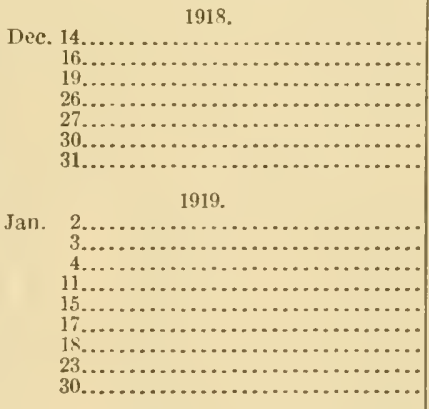 & $\begin{array}{r}58,000 \\
246,000 \\
40,000 \\
12,100 \\
23,000 \\
32,000 \\
8,000 \\
\\
50,000 \\
51,000 \\
15,300 \\
4,000 \\
126,000 \\
40,000 \\
250,000 \\
12,000 \\
22,000\end{array}$ \\
\hline
\end{tabular}

Rearrangement of these figures, as in Table IX, shows that 23.4 per cent of the counts are below 10,000 , and 76.4 per cent are below 50,000 . 
TABLE IX.-Result of arranging the bacterial counts of samples of reconstructed skimmed milk according to magnitude.

\begin{tabular}{|c|c|c|}
\hline Range of values. & $\begin{array}{l}\text { Number } \\
\text { of counts } \\
\text { within } \\
\text { range. }\end{array}$ & $\begin{array}{l}\text { Per cent } \\
\text { of counts } \\
\text { within } \\
\text { range. }\end{array}$ \\
\hline $\begin{array}{l}\text { Under } 10,000 \\
10,000-50,000 \\
50,000-100,000 \\
\text { Over } 100,000 \ldots \ldots\end{array}$ & $\begin{array}{r}8 \\
18 \\
4 \\
4\end{array}$ & $\begin{array}{l}23.4 \\
53.0 \\
11.8 \\
11.8\end{array}$ \\
\hline Total.................... & 34 & 100.0 \\
\hline
\end{tabular}

Table X gives the bacterial content of the butter used. A weighed amount of butter was added to sterile dilution water and the mixture warmed until the butter melted. This mixture was then shaken vigorously and the water layer analyzed. The results obtained are somewhat lower than might be expected.

TABLE X.-Bacterial content of butter.

\begin{tabular}{|r|r|}
\hline Date. & $\begin{array}{r}\text { Bacteria } \\
\text { per c.c. }\end{array}$ \\
\hline 1918. & \\
Oct. 22 & 38,000 \\
Nov. & 13,000 \\
22 & $2,000,000$ \\
30 & 250,000 \\
Dec. 3 & 280,000 \\
1919. & \\
Jan. 4 & 120,000 \\
17 & 650,000 \\
30 & 35,000 \\
\hline
\end{tabular}

Counts were also made from the milk as it passes from the mixing and pasteurizing vats to the emulsors. These are shown in Table XI.

TABLE XI.-Skimmed milk and butter mixture after pasteurization.

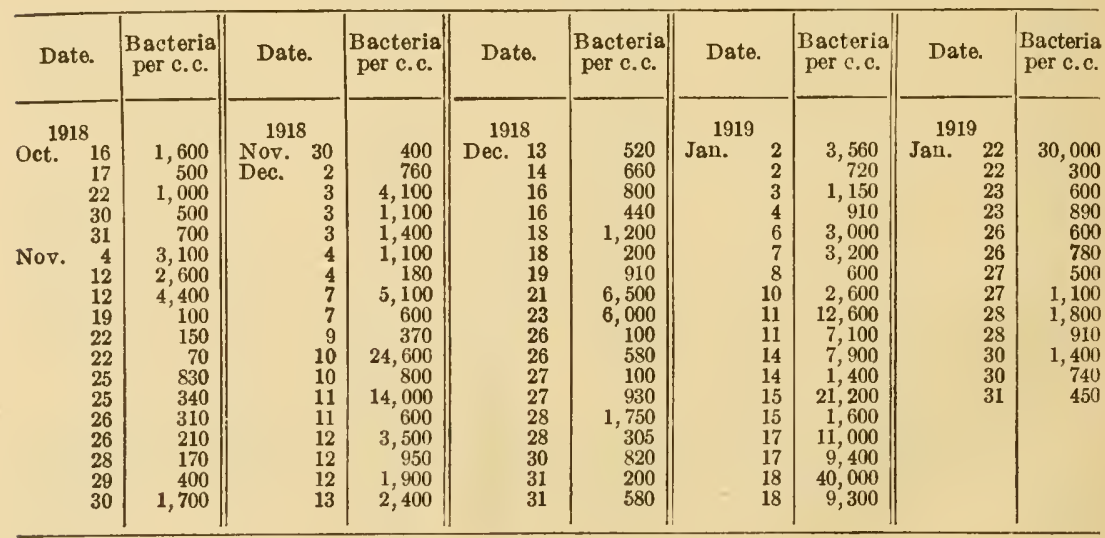


The killing of the bacteria in the butter and skimmed milk mixture depends, of course, on the length of time this mixture is heated. Samples taken at the first stages of a run or immediately after the 30-minute holding period, showed counts slightly higher than samples taken at the end of the emulsification period. This was due, of course, to the fact that the last of the mixture to flow from the mixing vats into the emulsors had approximately 45 minutes more heating at $146^{\circ} \mathrm{F}$. than did the first of the bateh. Typical results showing the variation in bacteria at the beginning and end of a batch are given in Table XII.

TABLE XII.-Difference in bacterial count at beginning and end of batch from emulsors.

\begin{tabular}{|r|r|r|}
\hline & \multicolumn{2}{|c|}{ Bacteria per c.c. } \\
\cline { 2 - 3 } Date. & $\begin{array}{c}\text { Begin- } \\
\text { ning. }\end{array}$ & End. \\
\hline 1918. & & \\
Dec . 1 & 1,400 & $4: 0$ \\
3 & 2,600 & 420 \\
11 & 7,200 & 720 \\
12 & 6,000 & 710 \\
16 & 1,300 & 450 \\
26 & 1,200 & 780 \\
1919. & 1,100 & 920 \\
Jan. 2 & 11,000 & 3,700 \\
\hline
\end{tabular}

Analyses were also made of the discharge from the emulsors and from the cooler. These figures show little if any rariation from the corresponding counts on the milk coming directly from the mixing vats, and are not given.

\section{Bacteriology of Cream.}

Bacteriological counts were also made on the reconstructed cream which was produced at Nitro. A summary of these results is given in Table XIII. These figures, rearranged in the order of their magnitude (Table XIV) show that 74.2 per cent of the counts were below 10,000 .

TABLE XIII.-Bacterial content of cream.

\begin{tabular}{|c|c|c|c|c|c|}
\hline & Date. & $\begin{array}{l}\text { Bacteria } \\
\text { per c. c. }\end{array}$ & & Date. & $\begin{array}{l}\text { Bacteria } \\
\text { per c.c. }\end{array}$ \\
\hline Nov. & 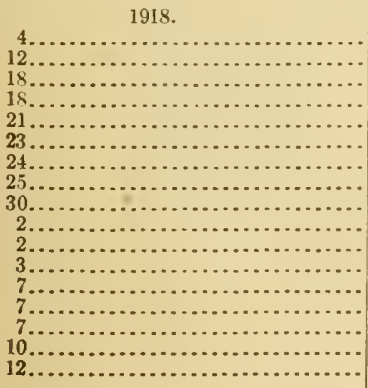 & $\begin{array}{r}2,200 \\
7,000 \\
4,000 \\
4,500 \\
1,500 \\
9,600 \\
400 \\
24,200 \\
25,000 \\
4,300 \\
2,000 \\
12,000 \\
6,000 \\
5,900 \\
5,100 \\
25,000 \\
72,000\end{array}$ & Dec. & 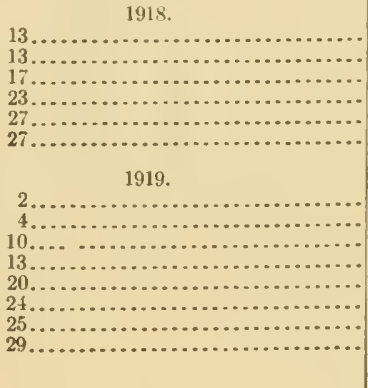 & $\begin{array}{r}5,300 \\
6,000 \\
6,200 \\
5,100 \\
27,000 \\
50,000 \\
3,200 \\
2,100\end{array}$ \\
\hline
\end{tabular}


TABLE XIV.-Results of arrangement of bacterial counts on reconstructed cream in order of magnitude

\begin{tabular}{|c|c|c|}
\hline Range of values. & $\begin{array}{l}\text { Number } \\
\text { of counts } \\
\text { falling } \\
\text { within } \\
\text { range. }\end{array}$ & $\begin{array}{l}\text { Per cent } \\
\text { of counts } \\
\text { falling } \\
\text { within } \\
\text { range. }\end{array}$ \\
\hline 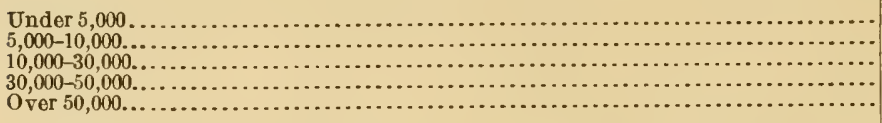 & \begin{tabular}{r|r}
12 \\
11 \\
5 \\
2 \\
1
\end{tabular} & $\begin{array}{r}38.7 \\
35.5 \\
16.1 \\
6.5 \\
3.2\end{array}$ \\
\hline Total..... & 31 & 100.0 \\
\hline
\end{tabular}

Bacterial Content of Ice-Cream Mix and Ice Cream.

There has been a decided controversy recently concerning the bacterial content of well-made ice cream, and many have taken the stand that it is impossible to produce good ice cream with a low bacterial count. At Nitro, ice cream was manufactured in a rather crude manner, one which would tend to give the product a much higher bacterial content than that produced with modern up-to-date machinery. The bacterial content of the ice-cream produced at Nitro was, therefore, determined with many misgivings, for it was thought that the figures might be misleading. Samples were taken of the mix shortly after it was manufactured and before any storage period had elapsed. Between the manufacture of the mix and the manufacture of the finished ice cream the mix was allowed to stand at a temperature of approximately $33^{\circ} \mathrm{F}$. for 24 hours. On manufacturing, the mix gave $95-100$ per cent "swell," showing that it was sufficiently aged to be commercially useful. Table XV gives the bacterial content of the ice-cream mix, and Table XVI that of the finished ice cream:

TABLE XV.-Bacterial content of ice-cream mix.

\begin{tabular}{|c|c|c|c|c|c|}
\hline Date. & $\begin{array}{l}\text { Bacteria } \\
\text { per c.c. }\end{array}$ & Date. & $\begin{array}{c}\text { Bacteria } \\
\text { per c.c. }\end{array}$ & Date. & $\begin{array}{l}\text { Bacteria } \\
\text { per c, e. }\end{array}$ \\
\hline \begin{tabular}{ll}
\multicolumn{1}{c}{1918.} \\
Oct. & 12 \\
Nov. 5 \\
11 \\
16 \\
18 \\
20 \\
21 \\
26 \\
26 \\
30 \\
30 \\
Dec. \\
2
\end{tabular} & $\begin{array}{l}1,700 \\
7,200 \\
2,100 \\
4,000 \\
1,300 \\
2,200 \\
800 \\
2,100 \\
7,000 \\
2,800 \\
1,600 \\
300\end{array}$ & $\begin{array}{rr}1918 . & \\
\text { Dec. } & 3 \\
3 \\
7 \\
9 \\
9 \\
10 \\
12 \\
14 \\
18 \\
21 \\
24 \\
24 \\
28\end{array}$ & $\begin{array}{r}2,200 \\
11,400 \\
15,000 \\
3,400 \\
4,600 \\
6,400 \\
15,400 \\
1,300 \\
1,700 \\
6,500 \\
22,600 \\
1,650\end{array}$ & \begin{tabular}{rr}
\multicolumn{2}{c}{1918.} \\
Dec. & 30 \\
1919. & \\
Jan. & 3 \\
& 8 \\
& 13 \\
17 \\
20 \\
21 \\
24 \\
24 \\
29 \\
30
\end{tabular} & $\begin{array}{r}5,000 \\
5,100 \\
6,700 \\
31,000 \\
5,000 \\
4,000 \\
6,000 \\
70,000 \\
1,200\end{array}$ \\
\hline
\end{tabular}


TABLE XVI.-Bacterial content of ice cream.

\begin{tabular}{|c|c|c|c|c|c|}
\hline Date. & $\begin{array}{l}\text { Bacteria } \\
\text { per c. c. }\end{array}$ & Date. & $\begin{array}{l}\text { Bacteria } \\
\text { per c.c. }\end{array}$ & Date. & $\begin{array}{l}\text { Bacteria } \\
\text { per c. c. }\end{array}$ \\
\hline $\begin{array}{rr}1918 . \\
\text { Nov. } 19 \\
21 \\
26 \\
30 \\
\text { Dec. } \quad 2 \\
7\end{array}$ & $\begin{array}{r}30,200 \\
2,000 \\
105,000 \\
23,000 \\
16,000 \\
4,500\end{array}$ & $\begin{array}{rr}1918 . \\
\text { Dec. } \quad 10 \\
12 \\
18 \\
21 \\
24 \\
28\end{array}$ & $\begin{array}{r}37,000 \\
7,000 \\
18,800 \\
27,200 \\
3,000 \\
1,500\end{array}$ & $\begin{aligned} & 1919 . \\
& \text { Jan. } \quad 20 \\
& \quad 21\end{aligned}$ & $\begin{array}{r}84,000 \\
9,0000\end{array}$ \\
\hline
\end{tabular}

Rearrangement of these figures shows that 79.5 per cent of the counts on the ice-cream mix were below 10,000, and 71.5 per cent of the counts on the finished ice cream were below 30,000. 'These figures indicate that, under average conditions, an ice cream can be manufactured with a bacterial content which approximates that of well-pasteurized creams.

\section{Butter-Fat Content of Reconstructed Milk.}

In the operation of a plant manufacturing reconstructed milk, one of the important features is the proper mixing of the ingredients so that the percentage composition of the various constituents are as stated on the final package. The butter used in the making of the products at Nitro was bought with the moisture content guaranteed to be not over 15 per cent. Enough samples of this butter were analyzed to show that the specifications were being complied with, but no detailed analyses were made on the various tubs of butter used from day to day. It was assumed always that the butter contained at least 85 per cent fat. Butter-fat determinations made on the finished product brought out the fact that the butter purchased in many cases had a moisture content much less than 15 per cent, making the fat content of the milk greater than was guaranteed. This fact points out the great need for butter analysis, both by the manufacturer and by the purchaser. The moisture content of a sample from every churning, at least, should be determined, and if possible this figure should be stamped on the tubs shipped. In all cases a sufficient amount of butter was added to the milk mix to give $3 \frac{1}{2}$ per cent fat, assuming the butter contained 85 per cent butter fat.

Analyses of bottled milk were taken at first which showed that some variation existed in the fat content of the various containers as put on the market. A study was made to determine whether the fat content of the reconstructed milk at different points in the emulsification of a single batch varied. The results of these analyses are compiled in Table XVII. Those values which are grouped around definite points have been averaged, giving the values shown in 
Table XVIII. These values have been plotted in Figure 8. It is easily seen that the fat content at the start is generally less than $3 \frac{1}{2}$ per cent, whereas at the end of the run it is much less than $3 \frac{1}{2}$ per cent. After 70 per cent of the bateh has been run through the emulsor, there is a decided falling off in the percentage of butter fat

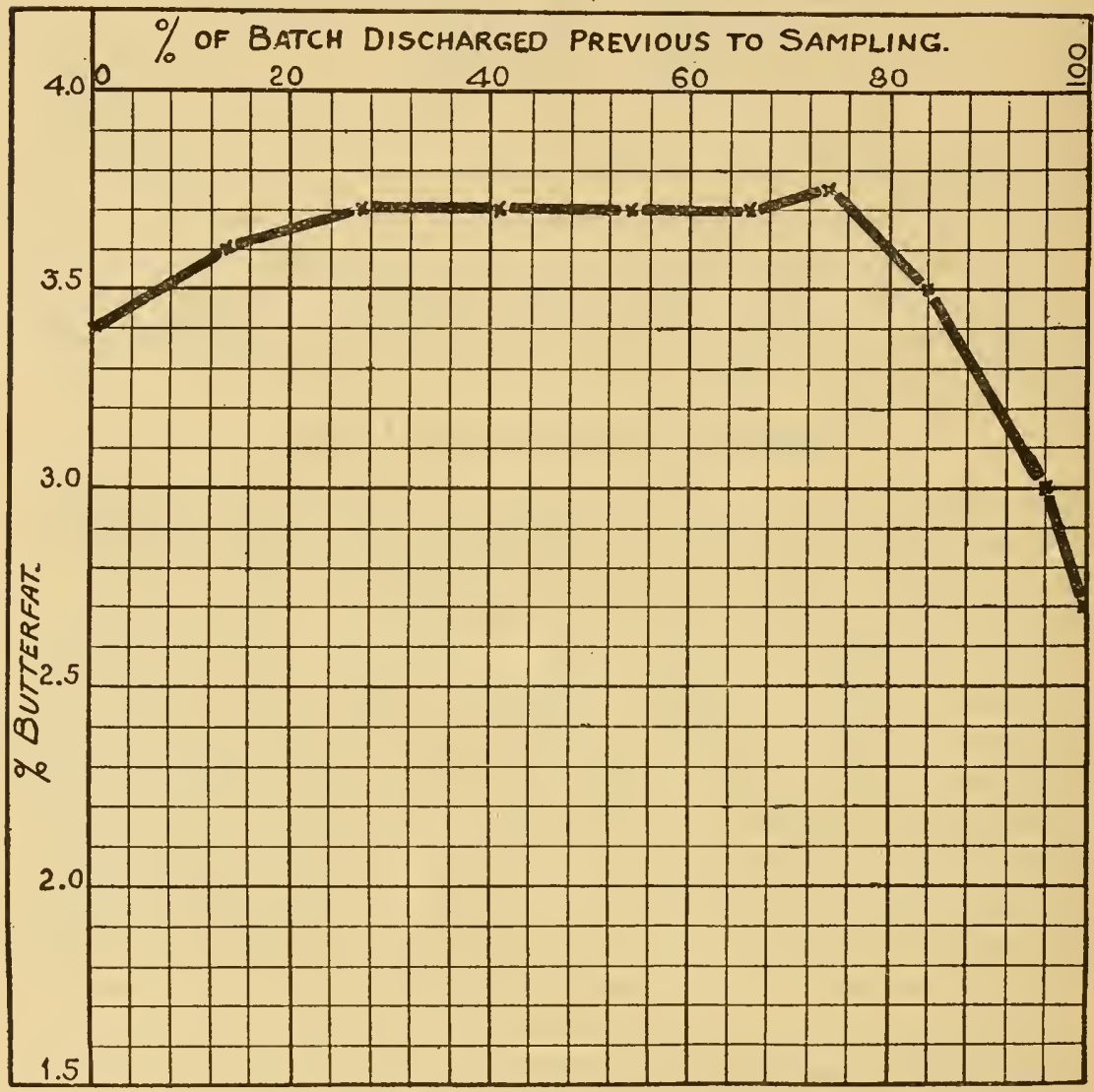

FIG. 8.-Variation in butter-fat content of reconstructed milk at various points in the manufacture of a single batch, Nitro, W. Va.

in the product. As the vat agitator is in continual motion during the whole process of the emulsion, the reason for the very consistent variation in fat content is not obvious. However, as the condition exists, a cold milk storage vat should be supplied with every installation to allow the equalization of the fat content before bottling. 
TABLE XVII.--Results of butter determinations made at various points during the emulsification of a batch of reconstructed milk.

\begin{tabular}{|c|c|c|c|c|c|c|c|c|c|c|c|c|c|c|c|c|c|}
\hline \multirow{2}{*}{\multicolumn{2}{|c|}{ Date. }} & \multicolumn{16}{|c|}{ Per cent of run discharged previous to sampling. } \\
\hline & & 0 & 3 & 12 & 13 & 14 & 16 & 25 & 27 & 28 & 29 & 38 & 40 & 42 & 43 & 50 & 53 \\
\hline $\begin{array}{c}1918 . \\
\text { Dec. } 11 \ldots \ldots \\
14 \ldots \ldots \\
14 \ldots \ldots \\
1919 \\
\text { Feb. } 8 . \ldots \ldots \\
10 \ldots \ldots \\
11 \ldots \ldots\end{array}$ & $\begin{array}{l}\ldots \ldots \\
\ldots \ldots \\
\cdots \cdots \\
\ldots \ldots \\
\cdots \cdots \\
\cdots \cdots\end{array}$ & $\begin{array}{l}3.5 \\
3.4 \\
3.4 \\
3.4 \\
3.1 \\
3.5\end{array}$ & $\begin{array}{c}\ldots \ldots \\
\cdots \ldots \\
3.4 \\
\cdots \cdots \\
\cdots \cdots\end{array}$ & $\begin{array}{r}3.5 \\
\cdots\end{array}$ & $\begin{array}{l}3.6 \\
3.6\end{array}$ & $\begin{array}{c}3.7 \\
\ldots \ldots \\
\ldots \ldots\end{array}$ & $\begin{array}{c}\cdots \\
3.7 \\
\cdots \cdots \\
\cdots\end{array}$ & $\begin{array}{l}3.7 \\
\cdots . .\end{array}$ & $\begin{array}{l}3.9 \\
3.8\end{array}$ & 3.s & $\begin{array}{c}3.6 \\
\cdots \\
\cdots\end{array}$ & $\begin{array}{l}3.7 \\
\cdots \cdots\end{array}$ & $\begin{array}{l}3.7 \\
3.8\end{array}$ & $\begin{array}{c}\cdots \\
\cdots \\
3.6 \\
\cdots \cdots \\
\cdots\end{array}$ & $\begin{array}{l}3.8 \\
\ldots \ldots \\
\ldots \ldots\end{array}$ & $\begin{array}{c}3.6 \\
3.6 \\
\ldots \ldots \\
\ldots \ldots \\
\ldots \ldots \\
\ldots \ldots\end{array}$ & $\begin{array}{r}\cdots \\
\cdots \\
\cdots \\
3.8 \\
3.8\end{array}$ \\
\hline \multirow{2}{*}{ 1)ate. } & \multicolumn{17}{|c|}{ Per cent of run discharged previous to sampling. } \\
\hline & 55 & 57 & 62 & 67 & 68 & 72 & 75 & 80 & 81 & 83 & 86 & 87 & 88 & 93 & 94 & 97 & 100 \\
\hline $\begin{array}{r}1918 . \\
\text { Dec. } 11 \ldots . . \\
14 \ldots \ldots \\
14 \ldots \ldots \\
1919 . \\
\text { Feb. } 8 \ldots \ldots \\
10 \ldots \ldots \\
11 \ldots \ldots\end{array}$ & $\begin{array}{l}3.5 \\
\ldots . .\end{array}$ & 3.9 & $\begin{array}{c}3.6 \\
\cdots . .\end{array}$ & $\begin{array}{l}3.8 \\
3.8\end{array}$ & $\begin{array}{r}3.7 \\
\cdots .\end{array}$ & $\ddot{3} .9$ & $\begin{array}{r}3.7 \\
3.6 \\
\cdots \cdots\end{array}$ & $\begin{array}{l}3.7 \\
3.7\end{array}$ & $\begin{array}{r}3.6 \\
\cdots . .\end{array}$ & $\begin{array}{c}3.3 \\
\cdots \cdots \\
\cdots\end{array}$ & $\ddot{3} .5$ & $\begin{array}{l}3.5 \\
3.7\end{array}$ & $\begin{array}{l}3.3 \\
\cdots . .\end{array}$ & $\begin{array}{l}3.2 \\
3.3\end{array}$ & $\begin{array}{c}\cdots \ldots \\
\cdots \ldots \\
3.0 \\
\cdots \ldots . \\
\cdots\end{array}$ & 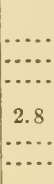 & $\begin{array}{l}2.7 \\
2.8 \\
3.2 \\
\\
2.3 \\
3.0 \\
2.0\end{array}$ \\
\hline
\end{tabular}

TABLE XVIII.-Average values of butter-fat determinations made at various points during the emulsification of a batch of reconstructed milk.

\begin{tabular}{|r|r|}
\hline $\begin{array}{c}\text { Per cent of } \\
\text { run dis- } \\
\text { charged } \\
\text { previous to } \\
\text { sampling. }\end{array}$ & $\begin{array}{c}\text { Per cent } \\
\text { butter fat. }\end{array}$ \\
\hline & \\
\hline 0 & \\
14 & 3.4 \\
27 & 3.6 \\
41 & 3.7 \\
54 & 3.7 \\
66 & 3.7 \\
74 & 3.7 \\
84 & 3.7 \\
95 & 3.5 \\
100 & 3.0 \\
& 2.7 \\
\hline
\end{tabular}

\section{Summary.}

1. Studies of the bacterial content of this plant's output of reconstructed milk and cream show that it was satisfactory from a health standpoint.

2. It has been demonstrated that satisfactory ice cream can be manufactured on a commercial scale, with a bacterial content comparable to that of well-pasteurized milk and cream.

3. Using the revolving coil type of ice-cream batch mixer for mixing the ingredients entering into reconstructed milk, a product of homogeneous fat content can not be made, and the final product from an entire batch should be mixed before bottling. 



$$
\text { PAT. JAN. 21, } 1908
$$

Syracuse, N.
PAT. JAK. 21, 1908




\section{LIBRARY OF CONGRESS}

|||||||||||||||||||||||||||||||||||||||||||||||||||||

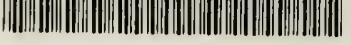

00008914654 